\title{
Towards A Comprehensive Learning Object Metadata: Incorporation of Context to Stipulate Meaningful Learning and Enhance Learning Object Reusability
}

\author{
Yazrina Yahya \\ National University of \\ Malaysia, Malaysia
}

\author{
Mohammed Yusoff \\ Open University of Malaysia \\ Kuala Lumpur, Malaysia
}

yaz@ftsm.ukm.my

\begin{abstract}
In recent years, the learning object (LO) concept has been introduced to allow sharing of smaller and portable learning materials on the Internet. Its features, concept, components, and other related matters have been fairly debated among researchers and practitioners. Attempts have been made to derive definition, model, and its working application. However, the failure to embed learning context and pedagogical instructional role within metadata has contributed to the significance of LO educational values. Despite the efforts taken by various research groups and researchers to propose metadata that exhibit the LO pedagogical role, the accomplishment of these works is geared towards specific education environments or institutions. Therefore, it is desirable to attain new metadata elements that will capture the LO context and pedagogical aspects and increase the reusability features applicable to any education setting or environment. It is the intention of this paper to describe the work done in providing a new metadata element based on theoretical analysis.
\end{abstract}

Keywords: Learning Object, LO, LO context, LO context insertion, Metadata, History metadata, Learning Style Metadata

\section{Introduction}

Electronic learning is the convergence of the web and learning on all levels that is made up of several learning methods that are enhanced or facilitated by technology. The use of a learning management system (LMS) in e-Learning environments allows content authoring and sequencing, and content delivery to learners. In addition, a LMS also assigns content lessons to learners and records their performance, thus creating a learner's profile. In other words, e-Learning of-

Material published as part of this publication, either on-line or in print, is copyrighted by the Informing Science Institute. Permission to make digital or paper copy of part or all of these works for personal or classroom use is granted without fee provided that the copies are not made or distributed for profit or commercial advantage AND that copies 1) bear this notice in full and 2) give the full citation on the first page. It is permissible to abstract these works so long as credit is given. To copy in all other cases or to republish or to post on a server or to redistribute to lists requires specific permission and payment of a fee. Contact Publisher@InformingScience.org to request redistribution permission. fers a one-location gateway to varieties of educational resources, such as electronic books, digital presentation, web-based lecture notes, case studies, and other types of educational learning materials. This contributes to the rise of digital learning materials in the education field. However, these learning materials need to be designed effectively, as e-Learning promotes online education, unlike the traditional 
method which emphasizes the face-to-face and instructor-centered way of teaching. In contrast, digital materials need to include multimedia presentation - where words and graphics are used together - to deliver the instruction, to adopt personalization principles, to initiate cognitive processing in learners, and to include practice exercise, as stated by Clark and Mayer (2003).

In brief, designing and developing digital learning materials requires a substantial amount of effort, as the materials need to be well-designed using various media integration that require an allocation of cost. The cost to design and develop digital learning materials is high and extensive and is equivalent to developing traditional materials, because these digital materials need to be built from scratch using textbooks, references, and past experiences as a guide. For instance, to develop web-based lecture notes requires a substantial amount of money, and inclusion of graphics and animation would double the cost, and, if simulation is included, the cost would quadruple (Downes, 2004), which shows that developing interesting and well-designed learning materials involves a substantially large investment.

Consequently, if each educational institution produces its own local materials, the cost would multiply. This is ineffective, as the cost can be reduced by sharing the same learning materials among institutions.

The advent of communication technology has made sharing possible through the use of the Internet, and this leads to the emergence of the learning object (LO) concept. The LO concept was introduced to allow sharing of small, portable learning materials on the Internet. The concept, however, is not new to the world of reusable learning materials. The idea of learning objects had already emerged in the early nineties (Persico, Sarti, \& Viarengo, 1992). The concept was then concerned with storing the learning materials into databases. From then on, the issue that emerged was the reuse of learning materials (Olimpo, Chioccariello, Tavella, \& Trentin, 1990; Rada, 1995; Sarti \& Marcke, 1995). Nevertheless, due to the exponential growth of the World Wide Web, the worldwide availability of easily accessible learning materials sparked the re-emergence of these old concepts in the late nineties, and these concepts are presently being further developed to generate knowledge and insights into storing and retrieving of learning materials.

However, the success of this concept is hindered by problems that arose in the current eLearning setting. Figure 1 summarizes the current trends in e-Learning environment leading to existing problems in LO matters and points out that there are a few main challenges that need to be addressed in order to ensure the success of LO. As such, this paper focuses on the problems relating to LO metadata contextual and reusability issues. The next section will look at the incorporation of meaningful learning into LO in order to provide context and retrievability of LO.

\section{Learning Object Metadata (LOM)}

The LO concept is made viable through the possibility of retrieving and reusing the objects in actual practical environment. The objects are retrieved and reused through the use of metadata concept, and its interoperability is achieved through the development of the LO repository. The customary intention for using metadata is to describe any information on the object used by information professionals, such as museum registrars, library cataloguers, and archivists. Nevertheless, due to technological advances in educational environment, metadata is later used to assist in LO retrievability (Yordanova, 2007). Presently the LO metadata standard produced by IEEE LTSC (2005) is used as the benchmark in LO metadata development. Its usage is further extended to certify the authenticity and context of the object content, to indicate the structure integrity, to provide data for research setting, and to relate to other learning objects (GillilandSwetland, 1998; Lougee, 2003). 


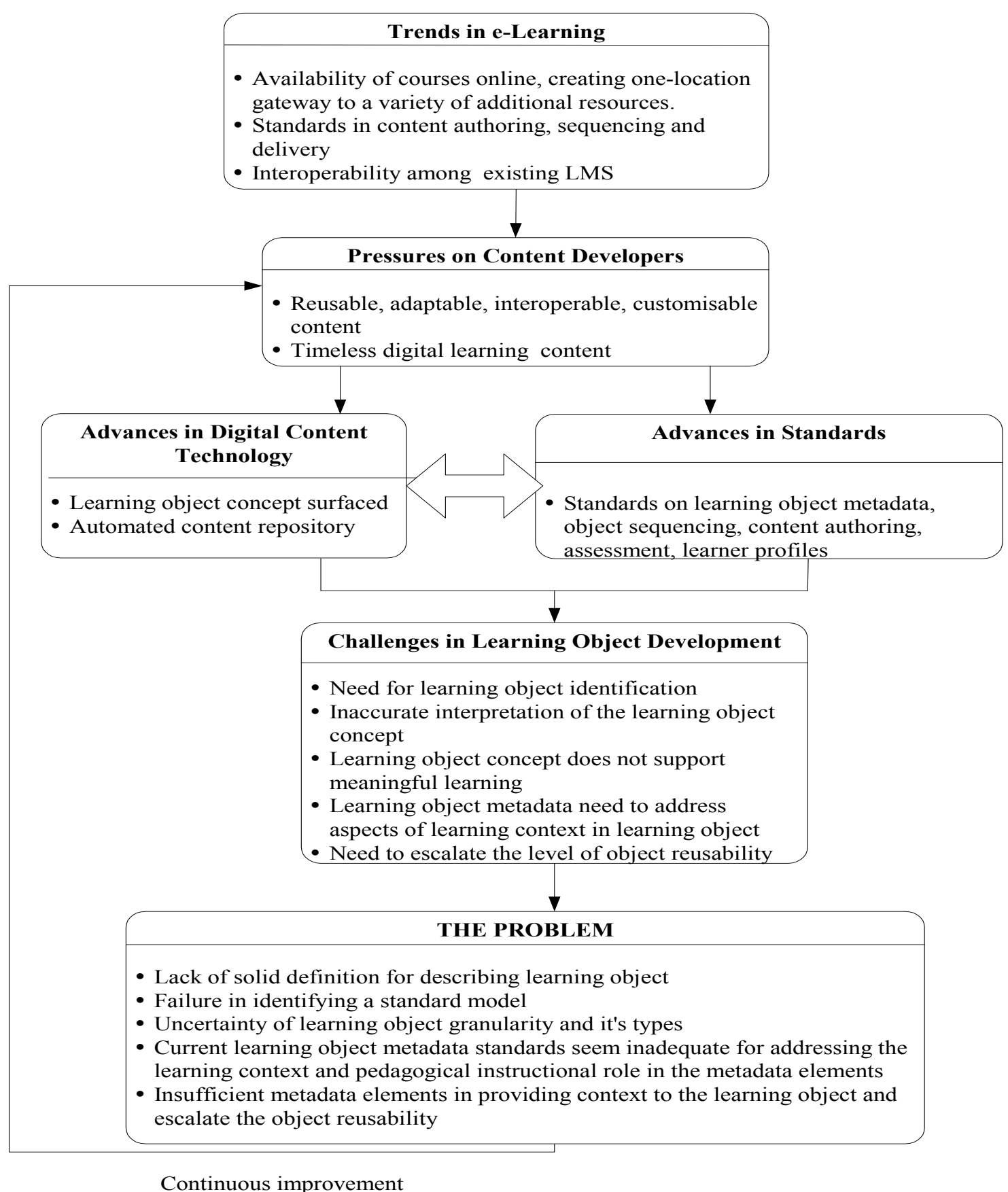

Figure 1: Current trends in e-Learning environment leading to the problems

The IEEE LOM standard (see Appendix) provides 77 metadata elements, which are distributed among nine categories. Although the existing LOM standard is widely adopted by LO practitioners and researchers world wide, its lack of contextual and pedagogical elements is currently much debated (Allert, Dhraief, \& Nejdl, 2001; Allert, Richter, Dhraief, \& Nejdl, 2004; Cowley \& Wesson, 2000; Friesen, 2004; Hepburn \& Place, 2000; McCarthy, 2000; Recker \& Walker, 2003; Recker \& Wiley, 2001; Robson, 2004; Sacks, Earle, Prnjat, Jarrett, \& Mendes, 2002; Yahya, Yusoff, \& Jenkins, 2001). The researchers argue that existing elements do not address all aspects of LO context and are merely used as a means of discovering, sharing, and reusing LO. The next section will look at issues relating to the incorporation of meaningful learning events, 
which are closely related to pedagogical and contextual aspects, and the issues of retrievability and reusability.

\section{LOM: Incorporation of Meaningful Learning Event}

Learning objects are known to be useful in the educational environment particularly for the academic purpose of providing learning activities to learners. However, there are concerns that learning objects are not able to support meaningful learning during the learning process (Jonassen \& Churchill, 2004; Wiley, 2003). Meaningful learning occurs when learners are able to remember, recall, understand, and reuse the knowledge to explain to others or apply it in their every day life. This requires learners to be engaged in meaningful tasks. In other words, meaningful learning will only occur when the learner becomes aware of the learning process and is engaged in the learning activity. According to activity theory (Jonassen \& Rohrer-Murphy, 1999), learning and activity are inseparable, and the key to enhancement in learning lies in the intimate connection between the desires for participation in the learning process/activity (Abbott, 1996). In other words, meaningful learning takes place in participating in an individual or community activity. Therefore, it can be concluded that meaningful learning is the product of building external connections between existing and new information (Hooper \& Rieber, 1995; Jonassen, Peck, \& Wilson, 1999; Mayer, 1984). It can make the learning process memorable and therefore, provides the ultimate learning experience.

However, with the current conceptualisation of learning objects, it is believed that learning objects do not cause learning but provide its availability. Koper and Es (2004) had the same notion whereby they stated that current learning objects had failed to fit into the context of learning, and meaningful learning had not occurred during the learning activity. Kraan and Wilson (2002) expressed their concern regarding the absence of meaningful learning due to the lack of pedagogical models in current LO standards. Koohang (2004) further emphasised the fact that LO's ultimate purpose was to enhance and facilitate learning.

As practitioners and researchers become aware of the importance of establishing meaningful learning, several approaches have been taken to incorporate activities that support meaningful learning. Most of this research is geared towards the design of LO content (Ip, Morrison, \& Curie, 2001; Ip, Young, \& Morrison, 2002; Krauss \& Ally, 2005; McLean \& Lynch, 2003). The motivation to design LO content and to incorporate meaningful learning had focused on principles of active engagement, and to elicit reflection and frequent communication as conducted by these respected researchers, namely Agostinho, Bennet, Lockyer, and Harper (2004), Berge and Fjuk (2003), Casey (2004), Luke, Mallory, and Atack (2004) and Zouaq, Nkambou, and Frasson (2007). Carefully designed learning objects have been proven to provide meaningful learning throughout the learning process (Jonassen, 2004). There are only a few research organisations that have focused on incorporating context or pedagogical aspects into the metadata element, namely CLEO (2001), CUBER (2004) and FAILTE (2002). However, the work done thus far is still insufficient as most were subjected to be of service to a specific learning environment or to the patron organisation. This leads to the attempt to provide more general metadata elements so that the context level is enhanced and pedagogical role is included in the LO using metadata method.

\section{LOM: Its Reusability}

Literature has shown that the number of vocabularies presented in LOM standards is limited in that they do not provide adequate instances of the elements to aid in the search process or to escalate the learning object reusability (Dillon, 2000). Sicilia and Garcia (2003) stressed the importance of measuring the LO reusability degree to verify that reusability is fully maximized and achieved when using learning objects. Duval and Hodgins (2004) and Sampson (2004) also 
mentioned the importance of having new metadata elements to promote reusability. This is essential to provide new ways of profiling to support reusability with minimum human interface.

Santally and Senteni (2005) stated that existing metadata elements that claimed to promote reusability are inadequate to fully support and maximize reusability features. New elements need to be incorporated to allow learners to obtain information regarding the objects' past usage, the users of the objects, the parent field of the object, and the usage setting or venue.

These concerns have led researchers to find ways to increase the reusability degree when using learning objects. Recker, Walker, and Wiley (2000) proposed the non-authoritative metadata that was able to capture the context of LO within instruction. The collaborative information filtering technique (Recker et al., 2000; Resnick \& Varian, 1997) was used to derive the nonauthoritative metadata. Hiddink (2001a) proposed that a history file be attached to the Unit Learning Material (ULM) which held knowledge about other useful courses or related courses to the ULM.

Garshol (2004) investigated the possibility of merging topic maps theory with metadata elements. The topic maps theory is used to represent a subject, which allows the subject based classification to be used to further classify the objects. Abel, Benayache, Lenne, and Moulin (2004), de Marchi, de Miranda, and Costa, (2005), Dichev, Dicheva, and Aroyo (2004), Dicheva, Dichev, and Wang, (2005), Dicheva, Dichev, Wang, and Zhu (2005), Fernandez, Moura, and Porto (2005) adopted Garshol's idea of utilizing topic maps in e-Learning modules. The topic maps are used to index and classify learning objects and aid the learners in viewing, navigating, and searching related metadata through categories provided. However, an analysis disclosed the deficiency of adopting this concept in the existing metadata elements. This led to the attempt of providing the resolution to the problem by incorporating the concept into current LOM standards.

\section{An Overview of the Investigation}

In determining the essential metadata element that would enhance LO context and reusability, a method as described in Figure 2 is adopted.

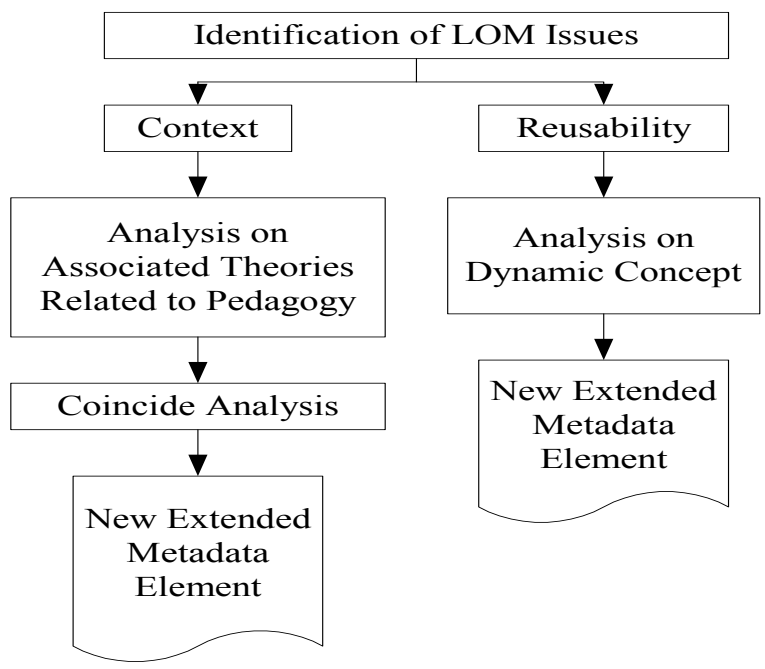

Figure 2: An Overview of the Investigation

The proposed extended metadata elements represented in Figure 2 are mainly dependent on the analysis performed and review of related theories. Details of the above process and the respective results are discussed in the following section. 


\section{New Extended Metadata Element: Context}

The determination of a new metadata or extended metadata element that addresses the context or pedagogical role is based on related theories. The associated theories and themes related to pedagogy matters identified are developmental theory, cultural diversity, classroom motivation and management, learning styles, learning theories, instructional design, and assessment. However, focus is given specifically to developmental theory, learning theories, instructional design, and learning styles as the other themes (i.e. cultural diversity, classroom motivation and management, and assessment) have broad vocabularies; therefore, it is difficult to determine specific vocabularies for the themes. In addition, classroom management and motivation involves traditional classroom method, which is different from the electronic learning method (the environment for learning objects) and irrelevant to the LO concept; therefore, they are excluded. Each theory and theme will be discussed in the subsequent sub-sections.

\section{Developmental theory}

Developmental theory provides the foundation for teachers or instructors to understand their learners by describing their development differences in systematic patterns. It provides information on how children's minds grow and develop. This helps teachers or instructors to respond more effectively to a learner's individual needs. It is important to understand a learner's development, as teaching strategies should match the physical, cognitive, and social development of the learner. By having information on learner's development, the curriculum may be designed and matched accordingly to the learner's abilities.

The developmental theory consists of cognitive, moral, and psychosocial development theories. Each of these theories provides insights on understanding a learner from different perspectives. The cognitive development theory has its roots back to Piaget's theory (1964), which described the ways humans gather and organize information and how this process changes during a child's developmental stages. Piaget recognized that development occurred in stages and that experiences helped learners to understand the world. The stages described by Piaget provided some information on how children develop and progress during their growing up years. The work of Piaget has helped in curriculum and instruction design. For instance, by using Piaget's theory, it is acknowledged that teachers or instructors should keep learners developmental needs in mind as they design and implement instruction. Therefore, when designing instruction using Piaget's theory, the instructors or teachers should provide concrete experiences that represent abstract concepts and principles. Besides, they should also provide links from concrete representation to abstract ideas.

Apart from Piaget's cognitive theory, Vygotsky $(1978,1993)$ provided an alternative perspective on the factors that influenced children's developing minds. The perspective by Vygotsky is known as sociocultural development theory, as it emphasizes social and cultural influences on the children's cognitive development. He viewed learning as arising directly from social interactions where the role of language is central to the theory. Therefore, in designing instruction using Vygotsky's perspective, one should include learning activities that involve learners in social interaction, encourage the use of language to express the learners' understanding, and provide instructional assistance to promote learning.

In addition, the moral development theory also has its roots back to Piaget's theories (1932, 1964) where he provided the different stages for children's responses to moral problems. His work was then used by Kohlberg (1963a, 1963b, 1984) to develop the moral development theory. Kohlberg described that moral development existed in three levels consisting of two stages each as illustrated in Table 1. His work led to the following conclusions (McDevitt \& Ormrod, 2002): everyone's reasoning passes through the same stages in the same order, where develop- 
ment is gradual and continuous, and once a stage is attained a person tends to reason at that stage not at stages lower than that. In conclusion, the moral development theory has helped teachers and instructors to understand learners' development and identify the behavior patterns of young people.

Table 1: Kohlberg's stages of moral development

\begin{tabular}{|c|c|}
\hline Level And Stage & Description \\
\hline Level 1: Preconventional Reasoning & $\begin{array}{l}\text { The ethics of egocentricity. Typical of children up to } \\
\text { about age ten. Called preconventional because young } \\
\text { children do not really comprehend the rules set down } \\
\text { by others. The consequences of the act determine if } \\
\text { it is good or bad. }\end{array}$ \\
\hline Stage 1: Punishment Obedience & The ethics of "What's in it for me" \\
\hline Stage 2: Market exchange & $\begin{array}{l}\text { Obeying rules and exchanging favors are judged in } \\
\text { terms of benefit to the person }\end{array}$ \\
\hline Level II: Conventional Ethics & $\begin{array}{l}\text { The ethics of others. Typical of ten to twenty year } \\
\text { olds. The name comes from conformity to the rules } \\
\text { and conventions of society. }\end{array}$ \\
\hline Stage 3: Interpersonal Harmony & $\begin{array}{l}\text { Sometimes called "Nice girl/good boy". Ethical de- } \\
\text { cisions are based on what pleases, helps or is ap- } \\
\text { proved of by others. }\end{array}$ \\
\hline Stage 4: Law and Order & $\begin{array}{l}\text { The ethics of order. Right is doing one's duty, obey- } \\
\text { ing the law and maintaining an orderly society. }\end{array}$ \\
\hline Level III: Postconventional Ethics & $\begin{array}{l}\text { The ethics of principle. Rarely reached before age } \\
\text { twenty and only by a small segment of the popula- } \\
\text { tion. Focuses on the principles underlying society's } \\
\text { rules. }\end{array}$ \\
\hline Stage 5: Social Contact & $\begin{array}{l}\text { Rules are based on principles of justice and common } \\
\text { good and are mutually agreed upon by members of } \\
\text { society. }\end{array}$ \\
\hline Stage 6: Universal Principles & $\begin{array}{l}\text { Rarely encountered in life. Ethics determined by in- } \\
\text { dividuals conscience guided by the abstract princi- } \\
\text { ples of justice and equality. }\end{array}$ \\
\hline
\end{tabular}

Source: Kohlberg, 1984

Psychosocial theory, on the other hand, focuses on the integration of personal, emotional, and social development. This theory states that a child's psychosocial development depends on the quality of care and support provided by social environment and, hence, a teacher's encouragement is essential. Therefore, in designing instruction, teachers or instructors must be aware of the learner's developmental changes and use the knowledge to structure the lesson or curriculum.

The theories reveal that teachers or instructors must or should be able to understand a learner's moral, cognitive, and psychosocial development. Although the importance of the theory is crystal clear, it is not relevant to be adopted as a metadata element. As such, usage of the theories for searching purposes may not be very useful due to the fact that metadata is used for search- 
ing documents or objects, and this requires the metadata to be simple, descriptive, and helpful in improving the efficiency of searching. The adoption of the developmental theory as a metadata element, on the other hand, could lead to difficulty in determining the values for the element as there are various theories and they involve other details that need to be included as the relevant value. This will create a complex hierarchy structure, which is not appropriate for metadata element values. In brief, the developmental theory is ruled out as a potential metadata element.

\section{Learning theories}

Learning theories are a set of related principles derived from observations that in turn are used to explain additional observations (Dorin, Demmin, \& Gabel, 1992). As learning theories have their roots in the psychological theory (Oon Seng, Parsons, Hinson, \& Sardo-Brown, 2003), they are used to understand critical issues raised in the study of learning, such as the mechanism of learning and transfer, the factors that influence learning, the roles of memory and motivation, the processes involved in self-regulation, and the implications for instruction. In addition, they are also used to provide the basics for instructional strategies development, which in turn is used for instructional design. For example, social cognitive theory helps by providing relevant information on placing learners in modeling roles, which were emphasized by the exercises given to students (Eggen \& Kauchak, 2004). Constructivism, on the other hand, emphasizes guided discovery and cooperative learning in which the exercises should include a variety of examples and promote a high level of interaction.

There is no doubt that learning theories play an important role in providing the basics for instructional design. However, if learning theory is to be adopted as a metadata element, it may not provide much contribution in increasing search efficiency. Therefore, learning theory is used in designing instruction but not as a point of access for searching (Large, Tedd, \& Hartley, 1999; Salim, Othman, \& Moi, 2005). Moreover, it is difficult to assign relevant values that may aid in searching processes. In addition, learning theory is not a descriptive element for an object but more of a foundation used to design the object. In brief, the theory does not provide appropriate features to allow its adoption as a metadata element; hence it is excluded from being a metadata candidate.

\section{Instructional design}

Instructional design is the systematic process of translating general principles of learning and instruction into plans for instructional materials, activities, information resources, and evaluations (Smith \& Ragan, 1999). The analysis of the theory and model reveals that they are used specifically in LO design and, as such, they are not relevant to be adopted as a metadata element or as a point of access for searching.

\section{Learning styles}

Kolb (1976) described learning styles as the individual's preferred method for assimilating information; it is an integral part of an active learning cycle. It is also referred to as an individual set of differences of personal preference for instruction or an association with a particular form of learning activity (Riding \& Rayner, 1999). Learning styles are determined by different groups of style models based on the learning process, the orientation of study, instructional preference, and cognitive development.

It is also an important concept to aid learning and to provide learning material guidance tailored to a learner's style of learning (Claxton \& Murrell, 1987). This leads to more effective learning (Claxton \& Murrell, 1987). Experiments performed by Schmidt (2004) revealed that including the right learning style would aid a learner's ability to expand his or her learning strategies. 
This indicates the importance of learning styles and its effects on the learner's performance. So, it is an excellent candidate for metadata elements as the theory details help to describe an object contextually. As noted by Sutton (2004) and Mason (2004), contextual attribute refers to any of the attributed explicit or implicit processes by which the learning objectives were achieved. In addition, it describes the object in detail and aids the information seekers to locate the object upon which they are empowered to decide its worthiness (Miller, 2004). This suggests the possibility of adopting learning styles as one of the metadata elements.

Further analysis on learning styles theory reveals that it is able to provide controlled vocabularies based on the types of learning styles available (Yordanova, 2007). This is in agreement with metadata needs whereby metadata should be coordinated and able to provide controlled vocabularies and application tools (Quam, 2004). In brief, learning styles have been determined as the new extended element that can provide context to learning objects (Yahya \& Yusoff, 2005b, $2005 \mathrm{c})$. Therefore, models on learning styles are further identified and analyzed. Table 2 provides the learning style models available. Each is subsequently discussed in detail.

Table 2: Models of learning styles

\begin{tabular}{|l|l|}
\hline Style Models & Description \\
\hline $\begin{array}{l}\text { Models Based on } \\
\text { the Learning Proc- } \\
\text { ess }\end{array}$ & $\begin{array}{l}\text { Model by Kolb (1976). The model is a two-dimensional model comprised } \\
\text { of perceptions, which are concrete/abstract thinking and processing (ac- } \\
\text { tive/reflective information processing). }\end{array}$ \\
\hline $\begin{array}{l}\text { Models Based on } \\
\text { Orientation to }\end{array}$ & $\begin{array}{l}\text { Model by Honey and Mumford (1986, 1992) provides preferred modes of } \\
\text { learning which shape an individual's approach to learning. } \\
\text { Model by Entwistle (1979) and Entwistle and Tait (1994) provides an inte- } \\
\text { gration of instructional preference to information processing in the learner's } \\
\text { approach to study. } \\
\text { Model by Biggs (1978, 1985) provides an integration of approaches to } \\
\text { study with motivational orientation. } \\
\text { Model by Schmeck, Ribich, and Ramanaiah (1977) provides the analysis } \\
\text { that occurs during learning, which relates to the distinctiveness, transferabil- } \\
\text { ity, and durability of memory and fact retention. }\end{array}$ \\
\hline $\begin{array}{l}\text { Models Based on } \\
\text { Cognitive Skills }\end{array}$ & $\begin{array}{l}\text { Model by Reinert (1976) provides a profile in terms of perceptual modality. } \\
\text { Model by Letteri (1980) provides a cognitive profile of three types of learn- } \\
\text { ers, which reflects their position in a bi-polar analytic-global continuum, } \\
\text { which reflects an individual's cognitive skills development. } \\
\text { Model by Keefe and Monk (1986) provides 24 elements in a learning style } \\
\text { construct, which is grouped into three dimensions. }\end{array}$ \\
\hline $\begin{array}{l}\text { Models Based on } \\
\text { Instructional Pref- }\end{array}$ & $\begin{array}{l}\text { Model by Price, Dunn, and Dunn (1977) and R. Dunn, Dunn, and Price } \\
\text { (1989) provides the learner's response to key stimuli, such as environmental } \\
\text { (light, heat), sociological (peers, pairs, adults, self), emotional (structure, } \\
\text { persistence, motivation), physical (auditory, visual, tactile), psychological } \\
\text { (global-analytic, impulsive-reflective). } \\
\text { Model by Grasha and Riechmann (1975) provides a social interaction } \\
\text { measure, which is used to develop three bipolar dimensions in a construct, } \\
\text { which describes a learner's typical approach to the learning situation. }\end{array}$ \\
\hline
\end{tabular}

Source: Riding \& Rayner, 1999 


\section{i) Models Based on the Learning Process}

The model was developed by Kolb (1976) and enhanced by Honey and Mumford (1986, 1992). Kolb's model identified four adaptive learning modes: concrete experience, reflective observation, abstract conceptualization, and active experimentation. It allows learners to have immediate concrete experience when fully involved in the learning activity; as such, learners are able to engage in abstract conceptualization that would aid in creating generalizations. This suggests that the learning process involves two fundamental elements: experience perceived and experience transformation.

Honey and Mumford (1992) attempted to enhance and develop the Learning Style Questionnaire (LSQ), which further use revealed learners as activists, theorists, pragmatists, and reflective of their discoveries. It is used particularly to explore implications for management situations and to improve individual or team performance.

Further investigation on the models, however, reveals that learning style is based on the learning process and this suggests that it is irrelevant as a metadata element or as search criteria. It is intricate and only known by the learning style theorists, therefore it is immaterial to the information seekers. The model is therefore excluded as metadata element candidate.

\section{ii) Model Based on Orientation to Study}

Entwistle (1979), Biggs (1978) and Schmeck et al. (1977) developed the model in stages. Entwistle developed a model consisting of four aspects: the meaning, reproducing, achieving, and holistic orientations. This leads to the identification of the integrated conception of learning process, which describes a series of learner actions linked to specific learning strategies. Entwistle's work focused mainly on the development of an empirical model of the processes underlying individual orientation in a general approach to learning.

Biggs (1978) further extended Entwistle's work by discovering motivational factors to develop a new measure of learning strategy. These motivational factors are labeled intrinsic, extrinsic, and achievement orientation, and as a result, the Study Process Questionnaire (SPQ) was produced to measure the extent these factors influence learners' learning approaches. Results from the experiment using SPQ reveal that there are three learning approaches: surface, deep, and achieving, and learners are categorized according to these approaches.

Schmeck et al. (1977) enhanced the model by including two forms of learning strategies known as reflective processing and agentic processing. An Inventory of Learning Processes (ILP) was developed to aid learners enhance their study approach. In brief, the model focused mainly on learning styles based on information processing concept. It therefore cannot be adopted as an element of the metadata as it is more beneficial in providing guidelines on learning approach, rather than as a search criteria or point of access.

\section{iii) Models Based on Cognitive Skill Development}

The models under this category are based on an approach to learning, which presume success only when a progressive development in skills and method is realized by the individual (Riding \& Rayner, 1999). The model was developed by Reinert (1976), Letteri (1980), and Keefe and Monk (1986).

Reinert (1976) provided a model to identify the individual's natural "perceptual modality" or perceptual condition in which the stimulation of one's sensory modality gives rise to an experience in another modality as he or she responds to the learning environment. The model, known as ELSIE, provided four categories of learning modality: visual, verbal, auditory, and activity based modalities. However, an analysis performed by Curry (1987) found that the model had limitations in the application of learning style. 
Letteri (1980), on the other hand, integrated several models of cognitive style to create a combined assessment of individual skills known as Cognitive Style Delineators (CSD). Although Letteri's work raised the key issues of the development of learning style and skills development, there was no published evidence to support the reliability or validity of CSD (Riding \& Rayner, 1999). The learning style profile (LSP) offered by Keefe and Monk (1986) aimed to produce an integrated model of styles. The style construct developed contained 24 key elements, grouped into three areas: cognitive skills, perceptual responses study, and instructional preferences. Although the LSP marked an important attempt to put an assessment based approach to utilizing learning style into operation, there is still little evidence to support the reliability of LSP.

In addition, based on DeBello (1990) and Curry (1987), the strongest reliable learning style model is from Dunn and Dunn model as explained in detail below.

\section{iv) Models Based on Instructional Preference}

Models based on instructional preferences suggest that matching instructional methods to learners' learning styles can lead to improved learning. Various models and perspectives are identified, namely models by K. Dunn and Dunn (1974), R. Dunn (1984), Grasha and Riechmann (1975), Kolb (1984), and Felder \& Silverman (1988). These models focus mainly on the instructional preference that affects the individual learning behavior, whereby learners need to choose the learning materials according to their learning style preferences.

Further analysis on the models reveals that the Dunn \& Dunn learning style model has been revised and is the most internationally used model for the past 30 years (R. Dunn, Thies, \& Honigsfeld, 2001). Therefore, this particular model has been adopted for further examination. Similar to K. Dunn \& Dunn's model (1974) is Felder \& Silverman's (1988) that provides similar domains; hence this model has also been adopted for further investigation. The examination reveals their similarities which are presented in Table 3.

Table 3: Comparison of Dunn and Dunn's model with Felder and Silverman's model

\begin{tabular}{|l|l|l|l|}
\hline \multicolumn{2}{|c|}{ Model Based on Dunn and Dunn } & Model Based on Felder and Silverman \\
\hline Domain & Elements & Domain & Elements \\
\hline Perceptual domain & $\begin{array}{l}\text { Auditory } \\
\text { Visual Picture } \\
\text { Visual Text } \\
\text { Tactile Kinaesthetic } \\
\text { Verbal (internal) }\end{array}$ & Perception & $\begin{array}{l}\text { Sensory } \\
\text { Intuitive }\end{array}$ \\
\hline Psychological & $\begin{array}{l}\text { Analytic } \\
\text { Global } \\
\text { Reflective } \\
\text { Impulsive }\end{array}$ & Input & \\
\hline Environmental & $\begin{array}{l}\text { Sound } \\
\text { Light } \\
\text { Temperature } \\
\text { Seating (design) }\end{array}$ & Processing & Visual \\
& $\begin{array}{l}\text { Time of day } \\
\text { Intake } \\
\text { Mobility }\end{array}$ & Understanding \\
Reflective
\end{tabular}




\begin{tabular}{|l|l|l|l|}
\hline Emotional & Motivation & & \\
& Persistence & & \\
& Conforming & & \\
\hline Structure & & \\
& Alone/Pairs & & \\
& Small Group & & \\
& Team & & \\
& Authority & & \\
& Variety & & \\
\hline
\end{tabular}

Further examinations on the models reveal their adoption potential as metadata element, as they offer verbal-visual dimension and the model domain elements are clearly outlined. Moreover, it would also draw information seekers to search for objects and use them according to their learning style preferences, which in turn would lead to more effective learning.

In brief, among the learning style models described above, further thorough investigation suggests that the model based on instructional preference is best adopted as the new extended metadata element. As such, the suggested vocabulary set and other technical details for learning style element, as in accordance to IEEE LTSC standard requirements, are described below.

Metadata Element Name: Learning Styles

The Recommended Vocabulary:Auditory/Verbal;

Visual

Sensory

Intuitive

Active

Reflective

Sequential

Global

Tactile Kinesthetic

Internal Kinesthetic

Impulsive

Team Interaction

Authority

Variety

Size: It is the frequency that an element is capable of being repeated. The values can be in terms of "smallest permitted maximum (smp)" where it relates to both the number of repetitions of an element (or element group) and to other number of characters to be accommodated by an element. It specifies the smallest number of repetitions or characters that systems must be able to accommodate for each element.

Smallest permitted maximum for learning styles: 10 items

Value space: Value space indicates the specific kind of values or content that can be associated with a particular element. It often corresponds to the datatype: CharacterString; Vocabulary (The value space is specified) or LangString, Datetime and Duration (The value space is unspecified)

Value space for learning styles: Specified vocabulary

Datatype: It is used for controlled vocabularies or lists of terms or numbers that are specified in advance for a particular element. In a web-based form or other human interface, these might be presented as a pull-down menu or pick-list. 
Datatype for learning styles: Vocabulary

Order: It is the importance of the sequence of the elements iterations. If an element is ordered, it signifies that the sequence of the element iterations is important and it will be sequenced in terms of importance or priority.

Order for the learning style: Ordered.

Figure 3 illustrates the learning style metadata element. The element number given is 5.12 in which 5 refers to the fifth category in the IEEE LOM standard (the educational category) and 12 is the sub-element number, extended from the existing 11. (See Appendix)

\begin{tabular}{|l|l|l|l|l|}
\hline $\begin{array}{l}\text { 5.12: Learning Style } \\
\text { Explanation }\end{array}$ & Size & Order & Value Space & Datatype \\
\hline $\begin{array}{l}\text { The preferred learning style of } \\
\text { the LO }\end{array}$ & $\begin{array}{l}\text { Smallest } \\
\text { permitted } \\
\text { maximum: } \\
10 \text { items }\end{array}$ & $\begin{array}{l}\text { Or- } \\
\text { dered }\end{array}$ & $\begin{array}{l}\text { Auditory/verbal } \\
\text { Visual } \\
\text { Sensory } \\
\text { Intuitive } \\
\text { Active } \\
\text { Reflective } \\
\text { Sequential } \\
\text { Global } \\
\text { Tactile kinaes- } \\
\text { thetic } \\
\text { Internal (and oth- } \\
\text { ers as described } \\
\text { in Table 3) }\end{array}$ & Vocabulary \\
& & & \\
\hline
\end{tabular}

Figure 3: Learning styles metadata element

\section{New Extended Metadata Element: Reusability}

Determining the extended metadata element to enhance reusability requires the use of dynamic concepts that require learners and experts to provide information on the LO's past usage and its usefulness in particular instructional contexts. This is appropriate, as learners are believed to have some form of domain knowledge or knowledge relating to the general area of the search objective (Michel, 1994) before using or while searching for a particular object. It is also necessary to determine the element vocabulary, as it aids in element design in working the LO system. The vocabulary is established by using topic maps concepts as it is organized around topics or subjects. Furthermore, it provides the association and occurrences for the topics discussed. A mapping exercise is formulated to deliver a representative construct based on topic maps concept, in which the representative construct will be appointed as the element vocabulary.

The representative constructs are not as exhaustive as the actual concept but it inhabits the main features of the actual concept. It is important to allow learners to obtain clear information on how the object was used in the past. The representative construct described in Figure 4 is appointed as the vocabulary element, in which related subjects and past usage are selected as the vocabulary. The topic construct was not chosen, as it had been described in other metadata subelement such as title and learning resource type. 


\begin{tabular}{|l|l|l|}
\hline \multicolumn{3}{|c|}{ Topic Maps Actual Concept } \\
\hline Construct & $\begin{array}{l}\text { Sub- } \\
\text { Construct }\end{array}$ & Description \\
\hline Topic & $\begin{array}{l}\text { The topic that } \\
\text { represents the topics } \\
\text { referred }\end{array}$ \\
\hline & $\begin{array}{l}\text { Topic } \\
\text { Names }\end{array}$ & $\begin{array}{l}\text { The name of the } \\
\text { topic i.e. formal } \\
\text { names, symbolic } \\
\text { names }\end{array}$ \\
\hline Types & $\begin{array}{l}\text { The kind of topic i.e. } \\
\text { meaning, term, } \\
\text { domain }\end{array}$ \\
\hline Occurrences & $\begin{array}{l}\text { Association } \\
\text { type }\end{array}$ & $\begin{array}{l}\text { Information } \\
\text { resources that are } \\
\text { relevant to the topic } \\
\text { the association type } \\
\text { i.e.: physical relation } \\
\text { (part-of; has-part etc) }\end{array}$ \\
\hline Association & $\begin{array}{l}\text { Occurrences } \\
\text { types }\end{array}$ & $\begin{array}{l}\text { The types of } \\
\text { occurrences i.e. } \\
\text { article, illustration }\end{array}$ \\
\hline topics one or more \\
betwoenship \\
\hline
\end{tabular}

\begin{tabular}{|l|l|l|}
\hline Construct & $\begin{array}{l}\text { Sub- } \\
\text { Construct }\end{array}$ & Description \\
\hline Topic & $\begin{array}{l}\text { The learning object that is } \\
\text { being referred to }\end{array}$ \\
\hline & $\begin{array}{l}\text { Topic } \\
\text { names }\end{array}$ & $\begin{array}{l}\text { The title of the learning } \\
\text { object (this can be } \\
\text { obtained from the general } \\
\text { element i.e. 1.2 } \\
\text { General.Title) }\end{array}$ \\
\hline & $\begin{array}{l}\text { Topic } \\
\text { Types }\end{array}$ & $\begin{array}{l}\text { The learning object types } \\
\text { (this can be obtained from } \\
\text { the Educational element } \\
\text { i.e. 5.2. } \\
\text { Educational.Learning } \\
\text { ResourceType) }\end{array}$ \\
\hline $\begin{array}{l}\text { Related } \\
\text { Objects/Subjects }\end{array}$ & $\begin{array}{l}\text { The subjects that are } \\
\text { relevant to the learning } \\
\text { object }\end{array}$ \\
\hline Past Usage & $\begin{array}{l}\text { The past usage of the } \\
\text { objects i.e. how it was } \\
\text { used in the past. }\end{array}$ \\
\hline
\end{tabular}

\section{Figure 4: Mapping exercise to obtain the representative construct}

In brief, other relevant information significant to history component development would be similar to any metadata element establishment, as such, it would include:

\section{Metadata Element Name: History \\ Metadata Sub-Element Name: $\quad$ Past Usage \\ Related Subjects}

The Recommended Vocabulary: NIL

Size: Smallest permitted maximum: 10 items

Order: Unspecified

Datatype: LangString (smallest permitted maximum 1,000 characters). LangString is combination of a language indicator and a string of characters. In other words, it represents one or more character strings.

Figures 5, 5.1, and 5.2 illustrate the history metadata element in detail. The history metadata proposed is extended under the educational element category, which is the fifth category in the IEEE LOM standard, as it is related to educational matters of the subject. As such the element number is given 5.13 , to describe the $5^{\text {th }}$ category and the $13^{\text {th }}$ sub-element in the category. (See Appendix) 


\begin{tabular}{|l|l|l|c|c|}
\hline $\begin{array}{l}\text { 5.13: History } \\
\text { Explanation }\end{array}$ & Order & Value Space & Datatype \\
\hline The history usage of the object & $\begin{array}{c}\text { Smallest } \\
\text { permitted } \\
\text { maximum: } \\
10 \text { items }\end{array}$ & Unspecified & - & $\begin{array}{c}\text { LangString } \\
\text { (smp: } 1,000 \\
\text { character) }\end{array}$ \\
$\qquad \begin{array}{l}\text { 5.13.1: Past Usage } \\
\text { 5.13.2: Related Subjects }\end{array}$ \\
\hline
\end{tabular}

Figure 5: History metadata

\begin{tabular}{|l|l|l|c|c|}
\hline $\begin{array}{l}\text { 5.13.1: Past Usage } \\
\text { Explanation }\end{array}$ & Order & Value Space & Datatype \\
\hline $\begin{array}{l}\text { Description on how the object } \\
\text { had been used previously }\end{array}$ & $\begin{array}{c}\text { Smallest } \\
\text { permitted } \\
\text { maximum: } \\
10 \text { items }\end{array}$ & Unspecified & - & $\begin{array}{c}\text { LangString } \\
\text { (smp: } 1,000 \\
\text { character })\end{array}$ \\
\hline \multicolumn{2}{|l|}{} & & & \\
\hline
\end{tabular}

Figure 5.1: Past usage sub-element

\begin{tabular}{|l|l|l|c|l|}
\hline $\begin{array}{l}\text { 5.13.2: Related Subjects } \\
\text { Explanation }\end{array}$ & Order & Value Space & Datatype \\
\hline $\begin{array}{l}\text { The subjects that are relevant to } \\
\text { the object }\end{array}$ & $\begin{array}{c}\text { Smallest } \\
\text { permitted } \\
\text { maximum: } \\
10 \text { items }\end{array}$ & Unspecified & - & $\begin{array}{c}\text { LangString } \\
\text { (smp: } 1,000 \\
\text { character) }\end{array}$ \\
\hline $\begin{array}{l}\text { This element indicates the educational subjects or educational topics that are relevant to the } \\
\text { object, where the object is used as an example, exercise or a part of a text and others. }\end{array}$ \\
\hline
\end{tabular}

\section{Figure 5.2: Related subjects sub-element}

Besides having history metadata element, it is also essential to extend the relation vocabulary to intensify LO reusability (Yahya \& Yusoff, 2005a, 2005b, 2005c). This is in agreement with Dillon (2000), who noted that in order for LO to be more reusable, the relation element should be used effectively by providing various types of relationship with more vocabularies incorporated into the element. Various researchers have mentioned the types of relation that are useful for connecting research domain models where they are used to illustrate the interconnection between two domains used (Dillon, 2000; El Saddik, Fischer, \& Steinmetz, 2001a, 2001b; Fischer, 2001; Seeberg et al., 2000); however, none have extended the vocabulary of the relation element to the existing IEEE LOM Standards. Therefore, the research examined the concept behind the theories and undermined the appropriate relations to best describe the relations between objects.

\section{a) Rhetorical relation}

Rhetorical relation is established through Rhetorical Structure Theory (RST) (Mann \& Thompson, 1987), which was initially developed as part of computer studies based on text generation. 
The theory further explained analysis of text coherence and relation between two spams of text, namely nucleus and satellite (Mann \& Thompson, 1988). A set of RST relations was identified as stated in Table 4. These relations are used to illustrate relation between texts and used in text generation, text indexing, automatic summarization, and new program generation from digital archives (Lindley, Davis, Nack, \& Rutledge, 2001). Therefore, rhetorical relation is potentially adopted to describe relationships between objects. This is in agreement with past works of El Saddik et al. (2001a, 2001b), El Saddik, Ghavam, Fischer, and Steinmetz (2000), Fischer (2001), and Seeberg et al. (2000), which used rhetorical relation to describe LO relationships with other objects. However, as these works do not provide details of rhetorical relations adopted, they are described here using IEEE LTSC standards and the latest set of rhetorical relation.

Table 4: Set of RST relations

\begin{tabular}{|l|l|l|}
\hline Nucleus-Satellite Relations & Background & Circumstance \\
\hline Antithesis & Condition & Elaboration \\
\hline Concession & Evaluation & Evidence \\
\hline Enablement & Volitional Cause & Volitional Result \\
\hline Interpretation & Motivation & Non-volitional cause \\
\hline Justify & Otherwise & Purpose \\
\hline Non-volitional result & Solutionhood & Summary \\
\hline Restatement & & \\
\hline
\end{tabular}

Multinuclear Relation

\begin{tabular}{|l|l|l|l|}
\hline Contrast & Joint & List & Sequence \\
\hline
\end{tabular}

Figure 6 provides the evidence of rhetorical relation adaptability as an extended vocabulary.

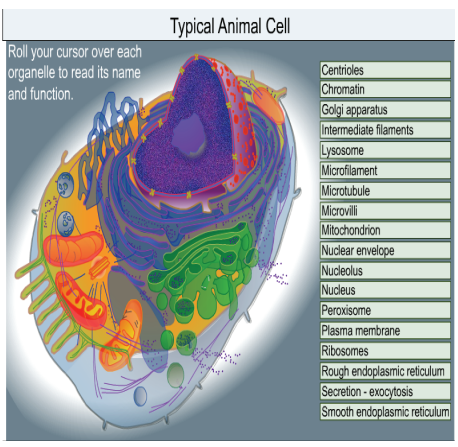

Object A

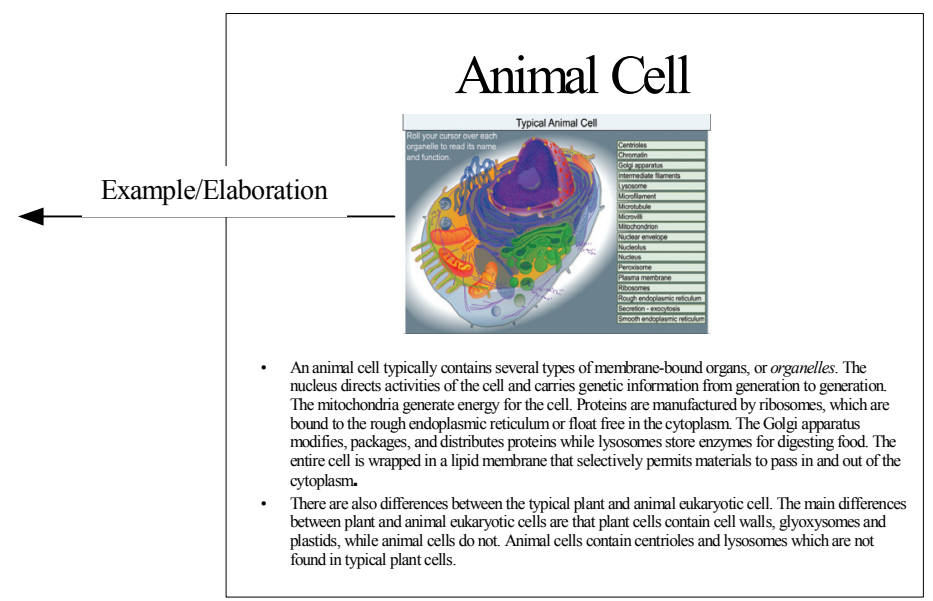

Object B

Figure 6: Use of rhetorical relation to describe object relationship 
Analysis performed on all possible RST relation suggests that relevant relations are suitable to describe LO relationships, which are detailed in Table 5.

Table 5: Selected relations to be extended as the vocabulary

\begin{tabular}{|l|l|}
\hline Relation & Definition \\
\hline Elaboration & Learning object A elaborates the content of learning object B \\
\hline Evidence & $\begin{array}{l}\text { Learning object B provides information to increase the belief } \\
\text { in the claim mentioned in learning object A }\end{array}$ \\
\hline Interpretation & Learning object B interprets or explains learning object A \\
\hline Justification & Learning object B justifies learning object A \\
\hline Summary & Learning object B summarizes learning object A \\
\hline Contrast/Opposite & The content of learning object A and B are opposites \\
\hline Condition/Restriction & Learning object B limits the content of learning object A \\
\hline Restatement/Alternative & $\begin{array}{l}\text { Learning object B provides an alternative of presenting learn- } \\
\text { ing object A }\end{array}$ \\
\hline Sequence & $\begin{array}{l}\text { Learning object B is the sequence or chronology of learning } \\
\text { object A }\end{array}$ \\
\hline Summary & Learning object B summarizes learning object A \\
\hline
\end{tabular}

Relations such as Antithesis, Concession, Evaluation, Enablement, Otherwise, Volitional Cause, Volitional Result, Purpose and Solutionhood are excluded as they are ambiguous when describing relation between objects.

\section{b) Semantic relation}

Semantic relation is a relation between meanings or concepts, in which it relates words and items with similar meanings. Hjørland (2005) underlined the existing kinds of semantic relations, as detailed in Table 6.

Table 6: Kinds of semantic relations

\begin{tabular}{|l|l|}
\hline Relation & Definition \\
\hline Active relation & $\begin{array}{l}\text { A semantic relation between two concepts, one of which expresses the } \\
\text { performance of an operation or process affecting the other }\end{array}$ \\
\hline Associative relation & A relation which is defined psychologically by the people \\
\hline Causal relation & A is the cause of B \\
\hline Hyponymous relation & A hierarchical subordinate relation \\
\hline Locative relation & A concept indicates a location of a thing designated by another concept \\
\hline Passive relation & $\begin{array}{l}\text { A relation between two concepts, one of which is affected to an opera- } \\
\text { tion or processed by the other }\end{array}$ \\
\hline Paradigmatic relation & $\begin{array}{l}\text { A relation between two concepts that is established by nature, self- } \\
\text { evident or by convention }\end{array}$ \\
\hline Related term & A term that is semantically related to another term \\
\hline Temporal relation & $\begin{array}{l}\text { A relation in which a concept indicated a time or period of an event } \\
\text { designated by another concept }\end{array}$ \\
\hline
\end{tabular}

Source: Hjørland, 2005 
Other types of semantic relation are also described in the Unified Medical Language MetaThesaurus (UMLS) (United States National Library of Medicine, 2005) and the Factotum Thesaurus (Cassidy, 2000) to present lexical knowledge base in thesaurus. Further analysis on these thesauruses reveals that the relations are divided into five categories: physical, spatial, temporal, functional, and conceptual. Table 7 further details the categories.

Table 7: Semantic relations detailed categories

\begin{tabular}{|l|l|}
\hline Semantic Relations Categories \\
\hline isa & [associated_with] (continued) \\
associated_with & [functionally_related] (continued) \\
physically_related_to & performs \\
part_of & carries_out \\
consist_of & exhibits \\
contains & practices \\
connected_to & generated_by \\
interconnects & occurs_in \\
branch_of & process_of \\
tributary_of & uses \\
ingredient_of & manifestation_of \\
component_of & indicates \\
spatially_related_to & result_of \\
location_of & temporally_related_to \\
adjacent_to & co_occurs_with \\
surrounds & precedes \\
traverses & conceptually_related \\
connected_to & evaluation_of \\
functionally_related_to & degree_of \\
affects & analyses \\
manages & assess_effect_of \\
treats & measurement_of \\
disrupts & measures \\
complicates & diagnoses \\
interacts_with & property_of \\
prevents & derivative_of \\
requires & developmental_form_of \\
brings_about & method_of \\
produces & conceptual_part_of \\
causes & issue_in \\
& has_meaning \\
& has_representation \\
\hline & applies_to \\
\hline
\end{tabular}

Analysis done on these thesauruses suggests that the categories and their relation are suitable for describing LO relationships as illustrated in Figure 7. The relations identified are therefore adopted as the extended vocabulary in the relation category and the sub-element is represented as 7.1 in Figure 8. 


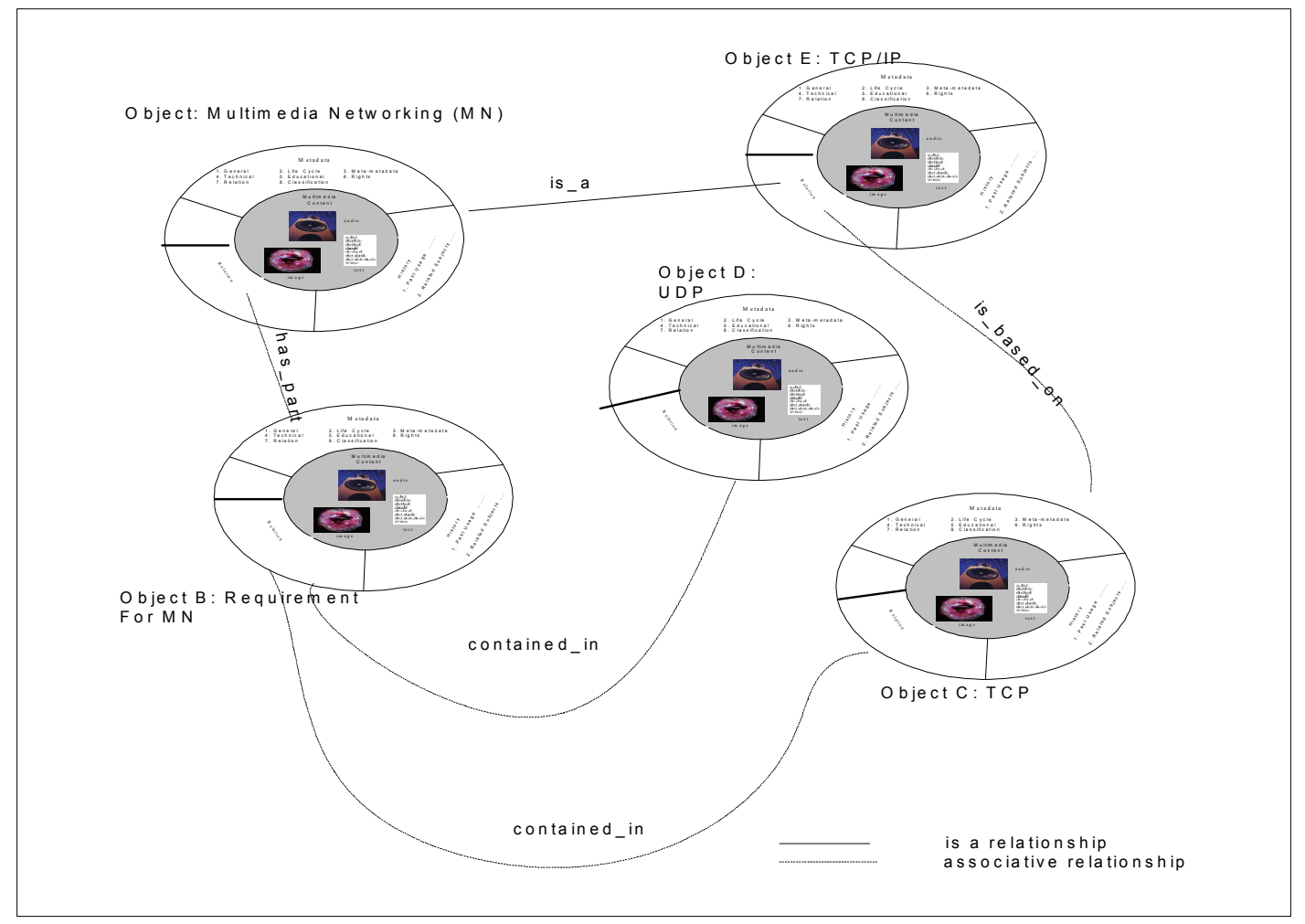

Figure 7: Learning objects relation using semantic relation

Figure 8 illustrates the relation metadata element in detail. The relation metadata element is the $7^{\text {th }}$ category in the IEEE LOM standard (see Appendix) and the kind sub-element is the $1^{\text {st }}$ subelement of the relation category.

\begin{tabular}{|l|l|l|l|l|}
\hline $\begin{array}{l}\text { 7.1: Kind } \\
\text { Explanation }\end{array}$ & Size & Order & Value Space & Datatype \\
\hline $\begin{array}{l}\text { This element defines the } \\
\text { relationship between the learning } \\
\text { objects and other learning } \\
\text { objects if there's any relationship } \\
\text { between the objects. }\end{array}$ & $\begin{array}{l}\text { Smallest } \\
\text { permitted } \\
\text { maximum: } \\
100 \text { items }\end{array}$ & Unordered & $\begin{array}{l}\text { Elaboration } \\
\text { Evidence } \\
\text { Interpretation } \\
\text { Justification } \\
\text { Summary } \\
\text { Associate with } \\
\text { (and others as } \\
\text { stated in Table 7) }\end{array}$ & - \\
& & & \\
\hline
\end{tabular}

This element is used to indicate associations between learning resources. The associations are in the form of relations and its sub-elements.

This element is used to indicate associations between learning resources. The associations are in the form of relations and its sub-elements. It does not describe the relations between metadata records.

Figure 8: Relation metadata 


\section{The Attestation of Extended Elements Viability}

The extended metadata elements derived, namely learning styles, history, and extended relation vocabulary, were applied in MELOR (Yahya \& Yusoff, 2005d) prototype system as proof that the metadata concept suggested is applicable and can be used by learners of MELOR or any digital repository.

The findings, as shown in Figure 9, suggest that such an application is possible, and further use of these elements can help learners to access objects according to their preferences compared to using a single search process. Apart from that, further use of the history element can help learners understand the object better as it provides relevant past usage of the object. This gives learners ideas on how the objects can be used, and if they want to view the particular object in its described environment, it is possible to do so through related URL provided in MELOR prototype system. This implies that the object is reusable as learners are able to access it in another context (i.e. other object kept in other learning environment, not in the system database) or in its current context (i.e. the object kept in the database). The related subject sub-element implemented in the history element provides additional information on the use of objects in other subject areas or disciplines. This adds value to the $\mathrm{LO}$ where learners are able to see its usage in other subject disciplines which they are not familiar with.

Generally the findings suggest that the extended metadata element is applicable and able to add value to a LO in terms of its usage and its ability to comply with learners' learning preference. This indicates that learners are able to improve their learning process as they are able to learn according to their inclination and able to understand more about other usage of the objects. This, consequently, promotes reusability.

\section{Conclusion}

The paper has described the procedure adopted to determine extended metadata element and the mechanism to attest the establishment of the elements. It is essential to provide new elements according to the IEEE LTSC LOM standard as it will allow the object practicability into a working Learning Object Repository (LOR) system and also promotes interoperability.

The enhancement of metadata elements is achieved by extending the current LO metadata standards with new elements (i.e. the learning styles, history, and extended relation vocabulary) that maximize the instructional use of the objects, provide learning context to learning objects, and maximize the objects reusability level. The findings suggest that the use of these extended metadata elements are useful to users as they are able to obtain and relate past usage information with the current LO, choose learning styles associated to their preference, and obtain additional information on objects relation to other objects. Therefore, when these extended elements are made available, they will provide support to promote reusability.

The findings of learning styles metadata element usage (Yahya \& Yusoff, 2005b, 2005c) are in agreement with Adkins and Brown-Syed (2002), Larkin-Hein (2000), Larkin-Hein and Budny (2003) and Mustaro and Silveira (2006), who noted that allowing learners to choose their learning style preferences had improved the learners' learning process and learning objects usage effectively. The learning styles metadata element proposed in this study is significantly different from those in previous works carried out by CLEO (2001), CUBER (2004) and FAILTE (2002). These research organizations, which have developed LO metadata application profiles, proposed extended elements to provide clear pedagogic intent and emphasis to the LO. However, the extended elements derived by these organizations are meant for specific use targeted for local usage and community in the specific region. Therefore, it is not suitable to be adopted by different target community or users. Furthermore, none of these researchers included learn- 
ing styles as their extended metadata element, indicating that this study is not only providing a fresh metadata element but is also global in nature to maximize LO instructional use.

The finding of history metadata element usage (Yahya \& Yusoff, 2005b, 2005c) is in agreement with Hiddink (2001a, 2001b) and Recker \& Wiley (2001) who noted that there was a need to develop a history element in the metadata. However, the history element derived in this study is significantly different from those in previous works, specifically Hiddink (2001a, 2001b) and Recker \& Wiley (2001) as these researchers did not use topic maps concept to describe the object relation to other objects and its past usage.

Recker \& Wiley (2001) adopted a collaborative filtering technique to receive input and comments from users, which is insufficient to promote LO reusability. Hiddink (2001a, 2001b) noted the importance of history files but further details and explanation on how it was developed and the concept used in developing the history element were not provided.

The findings of relation extended vocabulary described earlier (Yahya \& Yusoff, 2005a, 2005b, 2005 c) are in agreement with Dillon (2000), who noted that in order for the relation element to be used effectively in searching processes it should be able to provide various types of relationships where more vocabularies should be incorporated into the element. However, none of the previous researchers (Dillon, 2000; El Saddik et al., 2001a, 2001b; Fischer, 2001; Seeberg et al., 2000) extended the vocabulary of the relation element. These researchers mentioned the types of relation useful for connecting research domain models, which were used to illustrate the interconnection between the two domains used (i.e. the concept space and the media bricks). The relations identified were based on rhetorical relation and ontology theory. However, these relations were not further extended to the existing IEEE Learning Object Metadata (LOM)Standards. Although the theoretical knowledge used to extend the relation element is similar to previous studies (Dillon, 2000; El Saddik et al., 2001a, 2001b; Fischer, 2001; Seeberg et al., 2000), relations identified were different from those derived in earlier studies, particularly the relations obtained based on rhetorical relation theory and semantic relations as domain of the current research is different from those of previous ones. This paper has examined the concept behind the theories and has undermined the appropriate relations to best describe the relation between learning objects. 


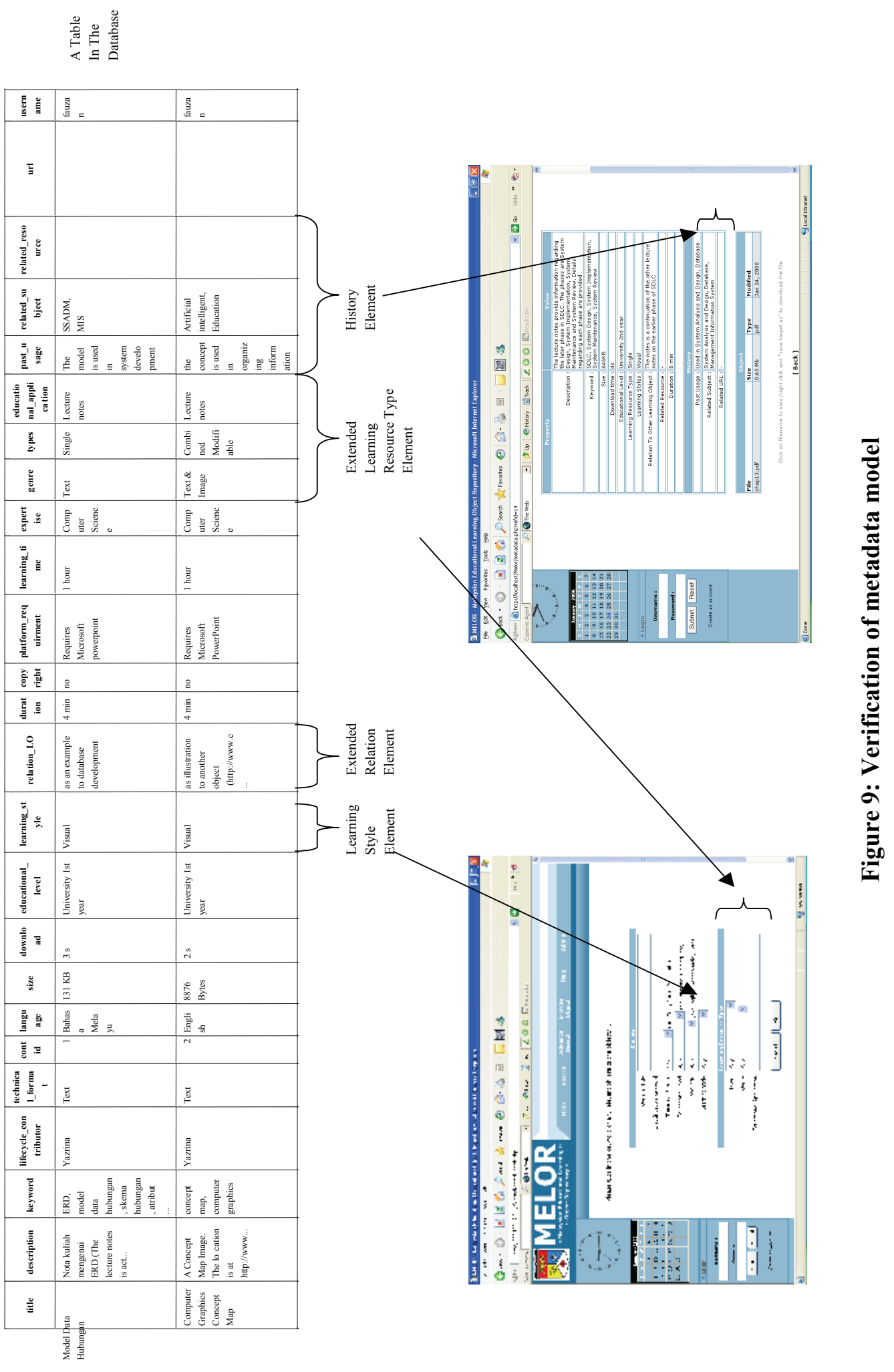




\section{References}

Abbott, J. (1996). 7 principles of learning: Challenging fundamental assumptions. New Horizons for Learning Electronic Journal, 2(3), 33-40.

Abel, M., Benayache, A., Lenne, D., \& Moulin, C. (2004). Ontology-based organizational memory for elearning. Educational Technology \& Society, 7(4), 98-111.

Adkins, D., \& Brown-Syed, C. (2002). Accommodating all learners: Critical inquiry and learning styles in the LIS classroom. Proceedings of the $68^{\text {th }}$ IFLA Council and General Conference. Libraries for Life: Democracy, Diversity, Delivery. August 18-24, 2002. Glasgow, Scotland IFLANET, 1-7.

Agostinho, S., Bennet, S., Lockyer, L., \& Harper, B. (2004). Developing a learning object metadata application profile based on LOM suitable for the Australian higher education context. Australasian Journal of Educational Technology, 20(4), 191-208.

Allert, H., Dhraief, H., \& Nejdl, W. (2001). Intelligent online-knowledge-resources for intentional learning. In P. Kommers \& G. Richard (Eds.), Proceedings of World Conference on Educational Multimedia, Hypermedia and Telecommunications 2001 (pp. 29-30). Chesapeake, VA: AACE.

Allert, H., Richter, C., Dhraief, H., \& Nejdl, W. (2004). Contextualized models and metadata for learning repositories In. R. McGreal (Ed.), Online education using learning objects (open and flexible learning) (pp. 182-193). London: RoutledgeFalmer.

Berge, O., \& Fjuk, A. (2003). Design of reusable learning objects. Poster Proceeding Computer Support for Collaborative Learning: Designing for Change in Networked Learning Environments, CSCL 2003 Congress: 14-18 June 2003, Bergen, Norway, 1-4.

Biggs, J. B. (1978). Individual and group differences in study processes. British Journal of Educational Psychology, 48, 266-279.

Biggs, J. B. (1985). The role of metalearning in study processes. British Journal of Educational Psychology, $55,185-212$.

Casey, J. (2004). If content is king, context is God! Secondary usage metadata \& resources in supporting web services for learning communities. Learning Technology, 6(1), 30-31.

Cassidy, P. (2000). An investigation of the semantic relations in the Roget's Thesaurus: Preliminary results. Proceedings CICLing-2000, International Conference on Intelligent Text Processing and Computational Linguistics, IPN Mexico, 181-204.

Clark, R. C., \& Mayer, R. (2003). e-learning and the science of instruction. Proven guidelines for consumers and designers of multimedia learning. San Francisco: Pfeiffer.

Claxton, C. S., \& Murrell, P. H. (1987). Learning styles: Implications for improving educational practice (ASHE-ERIC Higher Education Report, 1987, No 4). Washington: Jossey-Bass Inc. Publications.

CLEO. (2001). Customized learning experience. Retrieved May 6, 2001, from http://www.cleolab.org

Cowley, L., \& Wesson, J. (2000). Design patterns for web-based instruction. In J. Bourdeau \& R. Heller (Eds.), Proceedings of World Conference on Educational Multimedia, Hypermedia and Telecommunications (ED-MEDIA). Montreal, June 24 $4^{\text {th }}$-July $1^{\text {st }} .2000,2000(1)$ (pp. 250-255). Chesapeake, VA: AACE.

CUBER. (2004). Personalized curriculum builder in the Federated Virtual University of the Europe Origins. Retrieved December 14, 2005, from http://www.cuber.net/

Curry, L. (1987). Integrating concepts of cognitive on learning style: A review with attention to psychometric standards. Ontario: Canadian College of Health Service.

de Marchi, A. C. B., de Miranda, R. M., \& Costa, A. C. R. (2005). A learning objects repository management system for museum education. Proceedings of Museums and the Web 2005, April 13-16, 2005, Canada. Retrieved May 17, 2006, from http://www.archimuse.com/mw2005/papers/rocha/rocha.html 
DeBello, T.C. (1990). Comparison of eleven major learning styles: Variables, appropriate populations, validity of instrumentation, and the research behind them. International Journal of Reading, Writing and Learning Disabilities, 6, 203-222.

Dichev C., Dicheva D., \& Aroyo L. (2004). Using topic maps for web-based education. International Journal of Advanced Technology for Learning, 1(1), 1-7.

Dicheva, D., Dichev, C., \& Wang, D. (2005). Visualizing topic maps for e-learning. Fifth IEEE International Conference on Advanced Technologies (ICALT '05), 950-951.

Dicheva D., Dichev, C., Wang, D., \& Zhu, Y. (2005). Editing and exploring topic map-based e-learning repositories. Proceedings of 9 th IASTED International Conference Internet and Multimedia Systems and Applications Honolulu, Hawaii, August 15-17, 2005, 139-144.

Dillon, M. (2000). Metadata for web resources: How metadata works on the web. Proceedings of Bicentennial Conference on Bibliographic Control for the New Millennium. Confronting the Challenges of Networked Resources and the Web November 15-17, 2000. Washington, DC, 1-16.

Dorin, H., Demmin, P. E., \& Gabel, D. L. (1992). Chemistry: The study of matter (4th ed.). Massachusetts: Prentice Hall Needham.

Downes, S. (2004). Learning objects. Retrieved May 17, 2006, from http://www.downes.ca/files/Learning_Objects.htm

Dunn, K., \& Dunn, R. (1974). Learning style as a criterion for placement in alternative programs. Phi Delta Карра, 36, 275-279.

Dunn, R. (1984). Learning style: State of the science. Theory into Practice. 23(1), 10-19.

Dunn, R., Dunn, K., \& Price, G.E. (1989). Learning styles inventory. Kansas: Price Systems.

Dunn, R., Thies, A. P., \& Honigsfeld, A. (2001). Synthesis of the Dunn and Dunn learning-style model research: Analysis from a neuropsychological perspective. New York: St John's University Centre for the Study of Learning and Teaching Styles.

Duval, E., \& Hodgins, W. (2004). Learning objects revisited. In R. McGreal (Ed.), Online education using learning objects (open and flexible learning) (pp. 71-82). London: RoutledgeFalmer.

Eggen, P., \& Kauchak, D. (2004). Educational psychology. Windows on classrooms. (International edition. 6th ed.). New Jersey: Pearson /Merrill Prentice Hall.

El Saddik, A., Fischer, S., \& Steinmetz, R. (2001a, July-September). Reusable multimedia content in webbased learning systems. IEEE Multimedia, 30-38.

El Saddik, A., Fischer, S., \& Steinmetz, R. (2001b). Reusability and adaptability of interactive resources in web-based educational systems. ACM Journal of Educational Resources in Computing (JERIC), 1(1), 18-38.

El Saddik, A., Ghavam, A., Fischer, S., \& Steinmetz, R. (2000). Metadata for smart multimedia learning objects. Proceedings of the fourth Australasian Computing Education Conference. ACM-CSE, Melbourne, Australia, December 2000, 87-94.

Entwistle, N. J. (1979). Motivation, styles of learning and the academic environment. ERIC Document Reproduction Service ED 190 636. Edinburgh: University of Edinburgh Press.

Entwistle, N. J., \& Tait, H. (1994). The revised approaches to studying inventory. University of Edinburgh, Centre for Research into Learning and Instruction.

FAILTE. (2002). Facilitating access and information to learning and teaching resources for engineers. Retrieved December 14, 2005, from http://www.failte.ac.uk/

Felder, R. M., \& Silverman, L. K. (1988). Learning and teaching styles in engineering education. Engineering Education, 78(7), 674-681. 
Fernandez, A. P., Moura, A. M. de C., \& Porto, F. (2005). Using topic maps to represent learning objects in a learning content management system. Proceedings of the Semantic Web for Web-based Learning: Implications in the area of information systems in education. SW-WL '05 13-17 June 2005, Porto, Portugal, 701-718.

Fischer, S. (2001). Course and exercise sequencing using metadata in adaptive hypermedia learning systems. ACM Journal of Educational Resources in Computing (JERIC), 1(1), 1-21.

Friesen, N. (2004). Some objections to learning objects. In R. McGreal (Ed.), Online education using learning objects (open and flexible learning) (pp. 59-70). London: RoutledgeFalmer.

Garshol, L. M. (2004). Metadata? Thesauri? Taxonomies? Topic maps! Journal of Information Sciences, 30(4), 378-391.

Gillilland-Swetland, A. J. (1998). Defining metadata. In M. Bac (Ed.), Introduction to metadata pathways to digital information (pp. 1-8). Los Angeles: Getty Information Institute.

Grasha, A. F., \& Riechmann, S. W. (1975, Summer). Student learning styles questionnaire. Questionnaire exercise. Performed at University of Cincinnati Faculty Resource Centre, Ohio.

Hepburn, G., \& Place, G. (2000). Learning objects: Communicating the pedagogical potential. In L. Bourdeau \& R. Heller (Eds.), Proceedings of ED MEDIA 2000. World Conference on Educational Multimedia, Hypermedia and Telecommunication (pp. 1365-1366). Chesapeake, VA: AACE.

Hiddink, G. W. (2001a). Educational multimedia databases. Published Ph.D. Thesis, University Of Twente. Twente University: PressNetherlands.

Hiddink, G. W. (2001b). ADILE: Architecture of a database-supported learning environment. Journal of Interactive Learning Research 12(2/3), 297-315.

Hjørland, B. (2005). Lifeboat for knowledge organization lecture notes. Retrieved December 14, 2005 from http://www.db.dk/bh/lifeboat_ko/home.htm

Honey, P., \& Mumford, A. (1986). Using your learning styles. Maidenhead: Peter Honey.

Honey, P., \& Mumford, A. (1992). The manual of learning styles. Maidenhead: Peter Honey.

Hooper, S., \& Rieber, L. P. (1995). Teaching with technology. In A. C. Ornstein (Ed.), Teaching: Theory into practice (pp.154-170). Needham Heights: Allyn and Bacon.

IEEE LTSC. (2005). IEEE Learning Technology Standards Committee. Retrieved December 14, 2005, from http://ieeeltsc.org/

Ip, A., Morrison, I., \& Curie, M. (2001). What is a learning object technically? Proceedings of WebNet 2001 - World Conference on the WWW and Internet, Orlando, Florida, October 23-27, 2001, 580-586.

Ip, A., Young, A., \& Morrison, I. (2002). Learning objects - Whose are they? Proceedings of the $15^{\text {th }}$ Annual Conference of the National Advisory Committee on Computing Qualifications, 315-320.

Jonassen, D. H. (2004). Learning to solve problems: An instructional guide. San Francisco: Pfeiffer.

Jonassen, D. H., \& Churchill, D. (2004). Is there a learning orientation in learning objects? International Journal of E-Learning, 3(2), 32-41.

Jonassen, D. H., Peck, K. L., \& Wilson, B. G. (1999). Learning with technology. New Jersey: Merrill Publishing.

Jonassen, D. H., \& Rohrer-Murphy, L. (1999). Activity theory as a framework for designing constructivist learning environments. Educational Technology, Research \& Development, 47(1), 61-79.

Keefe, J. W., \& Monk, J. S. (1986). Learning styles profile examiner's manual. Reston: National Association of Secondary School Principals.

Kohlberg, L. (1963a). The development of children's orientations toward a moral order. 1: Sequence in the development of human thought. Vita Humana, 6, 11-33. 
Kohlberg, L. (1963b). Stages in development of moral thought and action. New York: Holt, Rinehart \& Winston.

Kohlberg, L. (1984). Essays on moral development, the psychology of moral development. (Vol. II). San Francisco: Harper\& Row.

Kolb, D. A. (1976). Learning style inventory: Technical manual. Englewood Cliffs: Prentice Hall.

Kolb, D. A. (1984). Experiential learning: Experience as the source of learning and development. New Jersey: Prentice-Hall.

Koohang, A. (2004). Creating learning objects in collaborative e-learning settings. Issues in Information Systems, 4(2), 584-590.

Koper, R., \& Es, R.V. (2004). Modelling units of learning from a pedagogical perspective. In R. McGreal (Ed.), Online education using learning objects (open and flexible learning) (pp. 43-58). London: RoutledgeFalmer.

Kraan, W., \& Wilson, S. (2002). Dan Rehak: "SCORM is not for everyone". The Centre for Educational Technology Interoperability Standards. Retrieved May 13, 2006, from http://www.cetis.ac.uk/content/20021002000737

Krauss, F., \& Ally, M. (2005). A study of the design and evaluation of a learning object and implications for content development. Interdisciplinary Journal of Knowledge and Learning Objects, 1, 1-22. Rettrieved from http://www.ijklo.org/Volume1/v1p001-022Krauss.pdf

Large, A., Tedd, L. A., \& Hartley, R. J. (1999). Information seeking in the online age: Principles and practice. London: Bowker Saur.

Larkin-Hein, T. (2000). Learning styles in introductory physics: Enhancing student motivation, interest and learning. Proceeding of International Conference on Engineering and Computer Education. August 2000. Sao Paolo, Brazil, 1-6.

Larkin-Hein, T., \& Budny, D. D. (2003). Learning styles in the physics classroom: A research-informed approach. Proceedings of the 2003 American Society for Engineering Education Annual Conference and Exposition, 1-14. Washington: American Society for Engineering Education.

Letteri, C. A. (1980). Cognitive profile: Basic determinant of academic achievement. Journal of Educational Research, 73, 195-199.

Lindley, C. A., Davis, J. R., Nack, F., \& Rutledge, L. W. (2001, January 31). The application of rhetorical structure theory to interactive news program generation from digital archives. CWI Centrum voor Wiskunde en Informatica Report. INS-R0101. The Netherlands.

Lougee, W. P. (2003). Diffuse Libraries. A community commons: Libraries in the new century. Association of Research Libraries Proceedings of the $142^{\text {nd }}$ Annual Meeting Lexington Kentucky May 14-17, 2003 Fred Heath, Texas A\&M, 53-61.

Luke, R., Mallory, D., \& Atack, L. (2004). Constructing context-based e-learning to support telehomecare communities of practice. Learning Technology, 6(1), 32-37.

Mann, W. C., \& Thompson, S. A. (1987). Rhetorical structure theory: A theory of text organization. Technical Report No. ISI/RS-87-190 NTIS Identifying Number ADA 183038. University of Southern California, Information Science Institute.

Mann, W. C., \& Thompson, S. A. (1988). Rhetorical structure theory: Toward a functional theory of text organization. Text, 8(3), 243-281.

Mason, J. (2004). Context and metadata for learning, education and training. In R. McGreal (Ed.), Online education using learning objects (open and flexible learning) (pp. 168-181). London: RoutledgeFalmer.

Mayer, R. (1984). Aids to text comprehension. Educational Psychologist, 19(1), 30-42. 
McCarthy, G. (2000). The structuring of context: New possibilities in an XML enabled World Wide Web. Journal of the Association for History and Computing, III (1), 1-12.

McDevitt, T., \& Ormrod, J. (2002). Child development and education. New Jersey: Merrill/Prentice Hall.

McLean, N., \& Lynch, C. (2003, June 28). Interoperability between information and learning environments - Bridging the gaps. A joint white paper on behalf of the IMS Global Learning Consortium and the Coalition for Networked Information. Florida.

Michel, D. (1994). What is used during cognitive processing in information retrieval and library searching? Eleven sources of search information. Journal of the American Society for Information Science, 45(7), 498-514.

Miller, P. (2004). Metadata- what it means for memory institutions. In G. E. Gorman \& D. G. Dorner (Eds.), Metadata Applications and Management. International Yearbook of Library and Information Management 2003/2004 (pp. 3-16). London: Facet Publishing.

Mustaro, P. N \& Silveira, I. F. (2006). Learning objects: Adaptive retrieval through learning styles. Interdisciplinary Journal of Knowledge and Learning Objects, 2, 35-46. Available at http://www.ijklo.org/Volume2/v2p035-046Mustaro.pdf

Olimpo, G., Chioccariello, A., Tavella, M., \& Trentin, G. (1990). On the concept of reusability in education design. Learning technology in the European communities. Proceedings of the Delta Conference on Research and Development - The Hague, 535-548.

Oon Seng, T., Parsons, R. D., Hinson, S. L., \& Sardo-Brown, D. (2003). Educational psychology. A practitioner-research approach (An Asian edition). Australia: Thomson.

Persico, D., Sarti, L., \& Viarengo, V. (1992). Browsing a database of multimedia learning material. Interactive Learning International, 8, 213-235.

Piaget, J. (1932). The moral judgment of the child. London: Routledge and Kegan Paul.

Piaget, J. (1964). Cognitive development in children: The Piaget papers. In R. E. Ripple \& V. N. Rockcastle (Eds.), Piaget rediscovered: A report of the conference on cognitive studies and curriculum development (pp. 6-48). New York: Cornell

Price, C. E., Dunn, R., \& Dunn, K. (1977). Learning style inventory research report. Kansas: Price Systems.

Quam, E. (2004). Metadata and taxonomy integration in government portals. In G. E. Gorman \& D. G. Dorner (Eds.), Metadata applications and management. International Yearbook of Library and Information Management 2003/2004 (pp. 95-108). London: Facet Publishing.

Rada, R. (1995). Hypertext, multimedia, and hypermedia. The New Review of Hypermedia and Multimedia, $1,1-21$.

Recker, M., \& Walker, A. (2003). Supporting 'word-of-mouth' social networks via collaborative information filtering. Journal of Interactive Learning Research, 14(1), 79-98.

Recker, M. \& Wiley, D. (2001). A non-authoritative educational metadata ontology for filtering and recommending learning objects. Journal of Interactive Learning Environments, 9(3), 255-280.

Recker, M., Walker, A., \& Wiley, D. (2000). An interface for collaborative filtering of educational resources. Proceedings of the 2000 International Conference on Artificial Intelligence (IC-AI'2000): June 26-29, 2000, Las Vegas, Nevada, USA, 317-323.

Reinert, H. (1976). One picture is worth a thousand words? Not necessarily! The Modern Language Journal, 60, 160-168.

Resnick, P., \& Varian, H. (Eds.). (1997). Recommender systems. Communications of the ACM (Special Issue), 40(3), 56-58. New York: ACM Press.

Riding, R., \& Rayner, S. (1999). Cognitive styles and learning strategies. Understanding style differences in learning behaviour. London: David Fulton Publishers. 
Robson, R. (2004). Learning objects, context and standards. In R. McGreal (Ed.), Online education using learning objects (open and flexible learning) (pp. 159-167). London: RoutledgeFalmer.

Sacks, L., Earle, A., Prnjat, O., Jarrett, W., \& Mendes, M. (2002). Supporting variable pedagogical models in network based learning environments. Engineering Education: Professional Engineering Scenarios IEEE, $1,22 / 1-22 / 6$.

Salim, J., Othman, M. S., \& Moi, L. T. (2005). Organisasi maklumat. Johor Bharu: Jasamex Enterprise.

Sampson, D. (2004). The evolution of educational metadata: From standards to application profiles. In Kinshuk, C. Looi, E. Sutinen, D. G. Sampson, I. Aedo, L. Uden \& E. Kähkönen (Eds.), Proceedings of the IEEE International Conference on Advanced Learning Technologies, ICALT 2004, 30 August - 1 September 2004, Joensuu, Finland (pp. 1072-1073). California: IEEE Computer Society.

Santally, M. I. \& Senteni, A. (2005). A learning object approach to personalized web-based instruction. European Journal of Open, Distance and E-Learning, 1, 1-16.

Sarti, L \& Marcke, K.V. (1995). Reuse in intelligent courseware authoring. In N. Major, T. Murray, \& C. Bloom (Eds.), AI-ED 95 Workshop on Authoring Shelles for Intelligent Tutoring Systems $-7^{\text {th }}$ World Conference on Artificial Intelligence in Education. Washington (U.S.A) - August 16-19, 1995 (pp. $82-$ 87). Washington: AACE.

Schmeck, R. R., Ribich, F. D., \& Ramanaiah, H. (1977). Development of a self-report inventory for assessing individual differences in learning processes. Applied Psychological Measurement, 1, 413-431.

Schmidt, K. (2004). A model to integrate online teaching and learning tools into the classroom. In. D. Cheek, \& J. Streichler (Eds.), Journal Of Technology Studies, 30(2) (pp. 86-92). Virginia: Virginia Techs Blacksburg.

Seeberg, C., Steinacker, A., Reichenberger, K., El Saddik, A., Fischer, S., \& Steinmetz, R. (2000). From the user's needs to adaptive documents. Proceedings of IDPDT'2000, Texas, USA, 41-49.

Sicilia, M-A., \& Garcia, E. (2003). On the concepts of usability and reusability of learning objects. International Review of Research in Open and Distance Learning, 4(2). Retrieved July 20, 2005, from http://www.irrodl.org/content/v4.2/sicilia-garcia.html

Smith, P. L., \& Ragan, T. J. (1999). Instructional design (2nd ed.). New Jersey: John Wiley \& Sons.

Sutton, S. A. (2004). Metadata and the education sector. In G. E. Gorman \& D. G. Dorner (Eds.), Metadata applications and management. International Yearbook of Library and Information Management 2003/2004 (pp. 141-160). London: Facet Publishing.

United States National Library of Medicine. (2005). Unified Medical Language System. National Institutes of Health. Retrieved December 14, 2005, from http://www.nlm.nih.gov/research/umls/

Vygotsky, L. S. (1978). Mind in society. Cambridge: Harvard University Press.

Vygotsky, L. S. (1993). The collected works of L. S. Vygotsky (Vol. 2) (J. Knox \& C. Stevens, Trans.). New York: Plenum.

Wiley, D. A. 2003. Learning objects: Difficulties and opportunities. Utah State University. Retrieved December 22, 2007, from http://opencontent.org:80//docs/lo_do.pdf

Yahya, Y., Yusoff, M., \& Jenkins, J. (2001). Quality metric for electronic learning: A framework for development. Proceedings of Quality Learning through Information \& Communication Technology. ICCE/SchoolNet 2001. Seoul, Korea. 12-15 November 2001, 3, 1611-1615.

Yahya, Y., \& Yusoff, M. (2005a). Learning object types and metadata extension: From theoretical perspectives. World Conference on Educational Multimedia, Hypermedia and Telecommunication. USA. 27 June- 2 July.

Yahya, Y., \& Yusoff, M. (2005b). The perception of a learning object model, its characteristics and metadata: From theoretical perspectives. E-Learn Conference. Vancouver, Canada. 24 - 28 October.. 
Yahya, Y., \& Yusoff, M. (2005c). The development of learning object model: Its types and metadata extension. Seminar Capaian Maklumat \& Pengurusan Pengetahuan. ICAMP 2005. Esset, Bangi 2005, 96104.

Yahya, Y., \& Yusoff, M. (2005d). MELOR: Malaysian educational learning object repository: towards achieving e-learning. Seminar Kebangsaan ICT Dalam Pendidikan 2005. Kuala Lumpur (CD-ROM).

Yordanova, K. (2007). Meta-data application in development, exchange and delivery of digital reusable learning content. Interdisciplinary Journal of Knowledge and Learning Objects 3, 229-237. Available at http://www.ijklo.org/Volume3/IJKLOv3p229-237Yordanova.pdf

Zouaq, A., Nkambou, R., \& Frasson, C. (2007). An integrated approach for automatic aggregation of learning knowledge objects. Interdisciplinary Journal of Knowledge and Learning Objects 3, 163-174. Available at http://www.ijklo.org/Volume3/IJKLOv3p135-162Zouaq.pdf

\title{
Appendix
}

\section{IEEE LTSC Learning Object Metadata Elements}

\author{
IEEE LTSC Metadata Elements Category and Detailed Description
}

\section{Category Sub-Elements Description}

1. General $\quad$ The category groups the general information that describes this learning object as a whole

It has sub elements such as:

1 Identifier: A globally unique label that identifies this learning object

1.1 Catalog: The name or designator of the identification or cataloguing scheme for this entry. A namespace scheme.

1.2 Entry: The value of the identifier within the identification or cataloguing scheme that designates or identifies this learning object. A namespace specific string

2 Title: The name given to this learning object

3 Language: The primary human language or languages used within this learning object to communicate to the intended user

4 Description: A textual description of the content of this learning object.

5 Keyword: A keyword or phrase describing the topic of this learning object. This data element should not be used for characteristics that can be described by other elements.

6 Coverage: The time, culture, geography or region to which this learning object applies.

7 Structure: Underlying organisational structure of this learning object

8 Aggregation Level: The functional granularity of this learning object 


\begin{tabular}{|c|c|}
\hline Category & Sub-Elem \\
\hline & $\begin{array}{l}\text { The category describes the history and the current state of the learning object } \\
\text { and those entities that have affected the learning object during its evolution } \\
\text { It has sub-elements such as: } \\
1 \text { Version: The edition of this learning object } \\
2 \text { Status: The completion status or condition of this learning object } \\
3 \text { Contribute: Those entities (i.e. people, organisations) that have contributed to } \\
\text { the state of this learning object during its life cycle (e.g. creation, edits, publi- } \\
\text { cation) } \\
3.1 \text { Role: Kind of contribution } \\
3.2 \text { Entity: The identification of and information about entities (i.e. people and } \\
\text { organisation) contributing to the learning object. The entities should be or- } \\
\text { dered as the most relevant first. } \\
3.3 \text { Date: The date of the contribution. }\end{array}$ \\
\hline & $\begin{array}{l}\text { The category describes the metadata record itself (rather than the learning object } \\
\text { that this record describes) } \\
\text { It has sub-elements such as: } \\
1 \text { Identifier: A globally unique label that identifies this metadata record } \\
1.1 \text { Catalog: The name or designator of the identification or cataloguing } \\
\text { scheme for this entry. A namespace scheme. } \\
1.2 \text { Entry: The value of the identifier within the identification or cataloging } \\
\text { scheme that designates or identifies this learning object. A namespace spe- } \\
\text { cific string } \\
\text { Contribute: Those entities (i.e. people, organisations) that have contributed to } \\
\text { the state of this learning object during its life cycle (e.g. creation, edits, publi- } \\
\text { cation) } \\
2.1 \text { Role: Kind of contribution. Exactly one instance of this data element with } \\
\text { value "creator" should exist } \\
\text { 2.2 Entity: The identification of and information about entities (i.e. people and } \\
\text { organisation) contributing to the learning object. The entities should be or- } \\
\text { dered as the most relevant first. } \\
2.3 \text { Date: The date of the contribution. } \\
\text { Metadata Schema: The name and the version of the authoritative specification } \\
\text { used to create this metadata instance } \\
4 \text { Language: Language of this metadata instance. This is the default language for } \\
\text { all the LangString values in this metadata instance }\end{array}$ \\
\hline
\end{tabular}




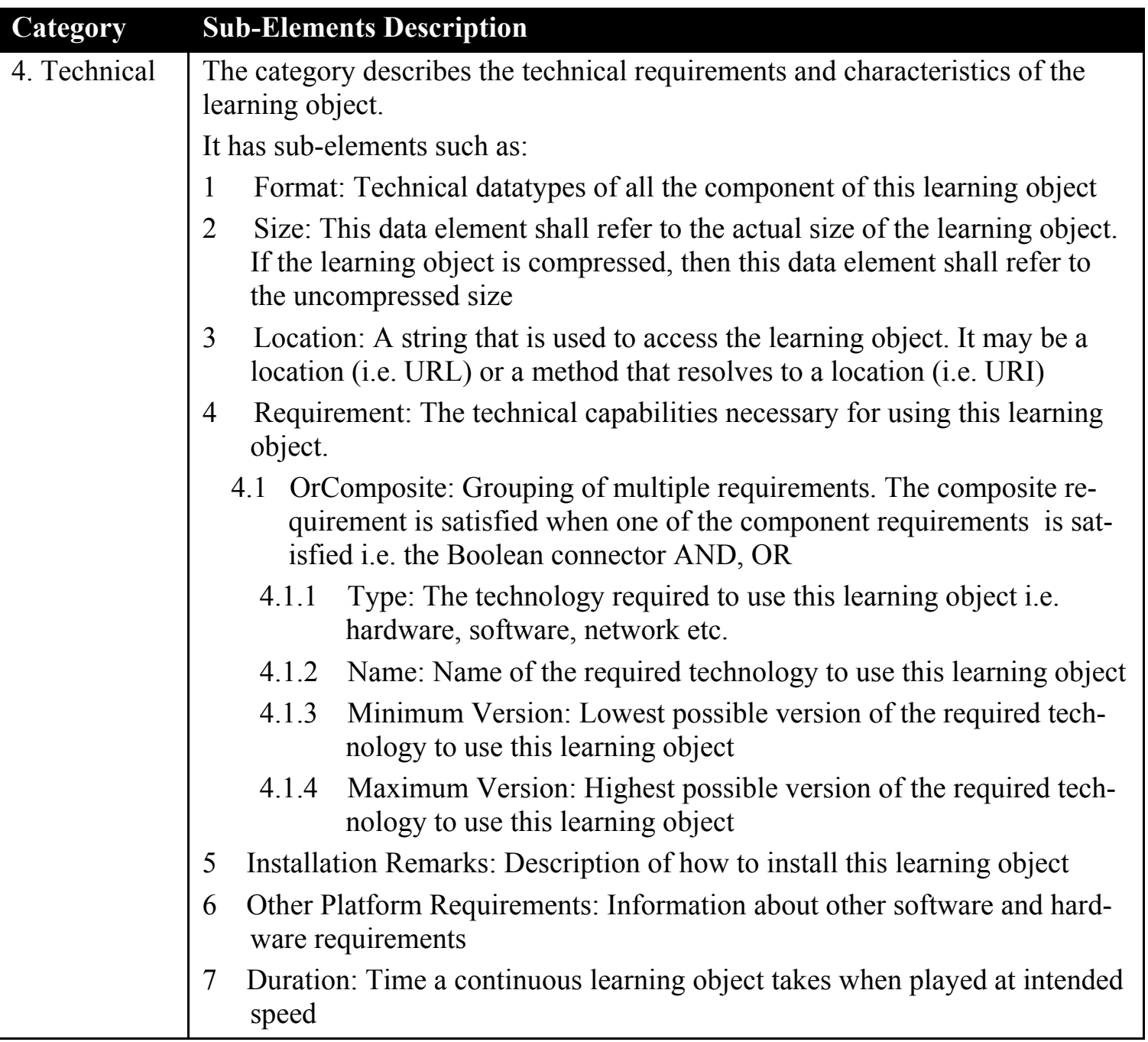




\begin{tabular}{|c|c|}
\hline Category & Sub-Elements Description \\
\hline 5. Education & $\begin{array}{l}\text { The category describes the key educational or pedagogic characteristics of the } \\
\text { learning object. } \\
\text { It has sub-elements such as: } \\
1 \text { Interactivity Type: Predominant mode of learning supported by this learn- } \\
\text { ing object. } \\
2 \text { Learning Resource Type: Specific kind of learning object. The most } \\
\text { dominant kind will be first. } \\
3 \text { Interactivity Level: The degree of interactivity characterizing the learning } \\
\text { object } \\
4 \text { Semantic Density: The degree of conciseness of a learning object. The se- } \\
\text { mantic density of a learning object may be estimated in term of its size, } \\
\text { span or - in the case of self-timed resources such as an audio or video- } \\
\text { duration. The semantic density of a learning object is independent of its } \\
\text { difficulty. It is best illustrated with examples of expositive material, al- } \\
\text { though it can be used with active resources as well } \\
5 \text { Intended User Role: Principal user for which this learning object was de- } \\
\text { signed, the most dominant first } \\
6 \text { Context: The principal environment within which the learning and use of } \\
\text { this learning object is intended to take place } \\
7 \text { Typical Age Range: Age of the typical intended user } \\
8 \text { Difficulty: How hard it is to work with or through this learning object for } \\
\text { the typical intended target audience. } \\
9 \text { Typical Learning Time: Approximate or typical time it takes to work with } \\
\text { or through this learning object for the typical intended target audience } \\
10 \text { Description: Comments on how this learning object is to be used } \\
\text { Language: The human language used by the typical intended user of this } \\
\text { learning object. }\end{array}$ \\
\hline
\end{tabular}




\begin{tabular}{|c|c|}
\hline Category & Sub-Elements Description \\
\hline 6. Rights & $\begin{array}{l}\text { The category describes the intellectual property rights and conditions of use for } \\
\text { the learning object } \\
\text { It has sub-elements such as: } \\
1 \text { Cost } \\
2 \text { Copyright and Other Restrictions } \\
3 \text { Description }\end{array}$ \\
\hline 7. Relation & $\begin{array}{l}\text { The category defines the relationship between the learning object and other } \\
\text { learning object. } \\
\text { It has sub-elements such as: } \\
1 \text { Kind: It describes the nature of the relationship between this learning object } \\
\text { and the target learning object } \\
2 \text { Resource: This element refers to the target learning object (the referenced } \\
\text { LO/the other LO) that this relationship references } \\
2.1 \text { Identifier: This element describes the unique label that identifies the tar- } \\
\text { get learning object (the referenced learning object) } \\
\text { 2.1.1 Catalog: The element describes the name or designator of the identi- } \\
\text { fication or cataloging scheme for this entry, A namespace scheme } \\
\text { 2.1.2 Entry: The element describes the value of the identifier within the } \\
\text { identification or cataloging scheme that designates or identifies the } \\
\text { target-learning object (the reference learning object) } \\
\text { 2.2 Description: This element provides the description of the target learning } \\
\text { object (referenced learning object) }\end{array}$ \\
\hline 8. Annotation & $\begin{array}{l}\text { The category provides comments on the educational use of the learning object } \\
\text { and information on when and by whom the comments were created. } \\
\text { It has sub-elements such as: } \\
1 \text { Entity: This element describes the entity (i.e. people, organizations) that cre- } \\
\text { ated the annotation } \\
2 \text { Date: The date of the contribution } \\
3 \text { Description }\end{array}$ \\
\hline
\end{tabular}




\begin{tabular}{|c|c|}
\hline Category & Sub-Elements Description \\
\hline $\begin{array}{l}\text { 9. Classifica- } \\
\text { tion }\end{array}$ & $\begin{array}{l}\text { The category describes where the learning object falls within a particular clas- } \\
\text { sification system. } \\
\text { It has sub-elements such as: } \\
1 \text { Purpose: This element describes the purpose of classifying this learning } \\
\text { object } \\
2 \text { Taxonpath: This element indicates the taxonomic path in a specific classi- } \\
\text { fication system. Each succeeding level is a refinement in the definition of a } \\
\text { proceeding level. There may be different paths, in the same or different } \\
\text { classifications, which describe the same characteristic } \\
2.1 \text { Source: This element describes the name of the classification system } \\
2.2 \text { Taxon: This element describes a particular term within a taxonomy. A } \\
\text { taxon is a node that has a defined label or term. A taxon may also have } \\
\text { an alphanumeric designation or identifier for standardized reference. } \\
\text { Either or both the label and the entry may be used to designate a par- } \\
\text { ticular taxon. } \\
\text { 2.2.1 Id: This element describes the textual label of the taxon } \\
\text { 2.2.2 Entry: This element describes the textual label of the taxon } \\
\text { Description: This element provides the description of the learning object } \\
\text { relative to the stated 9.1:Classification.Purpose of this specific classifica- } \\
\text { tion such as discipline, idea, skill level, educational objective etc } \\
4 \text { Keyword: Keywords and phrases descriptive of the learning object relative } \\
\text { to the stated 9.1:Classification.Purpose of this specific classification such } \\
\text { as accessibility, security, level etc most relevant first }\end{array}$ \\
\hline
\end{tabular}


Towards A Comprehensive Learning Object Metadata

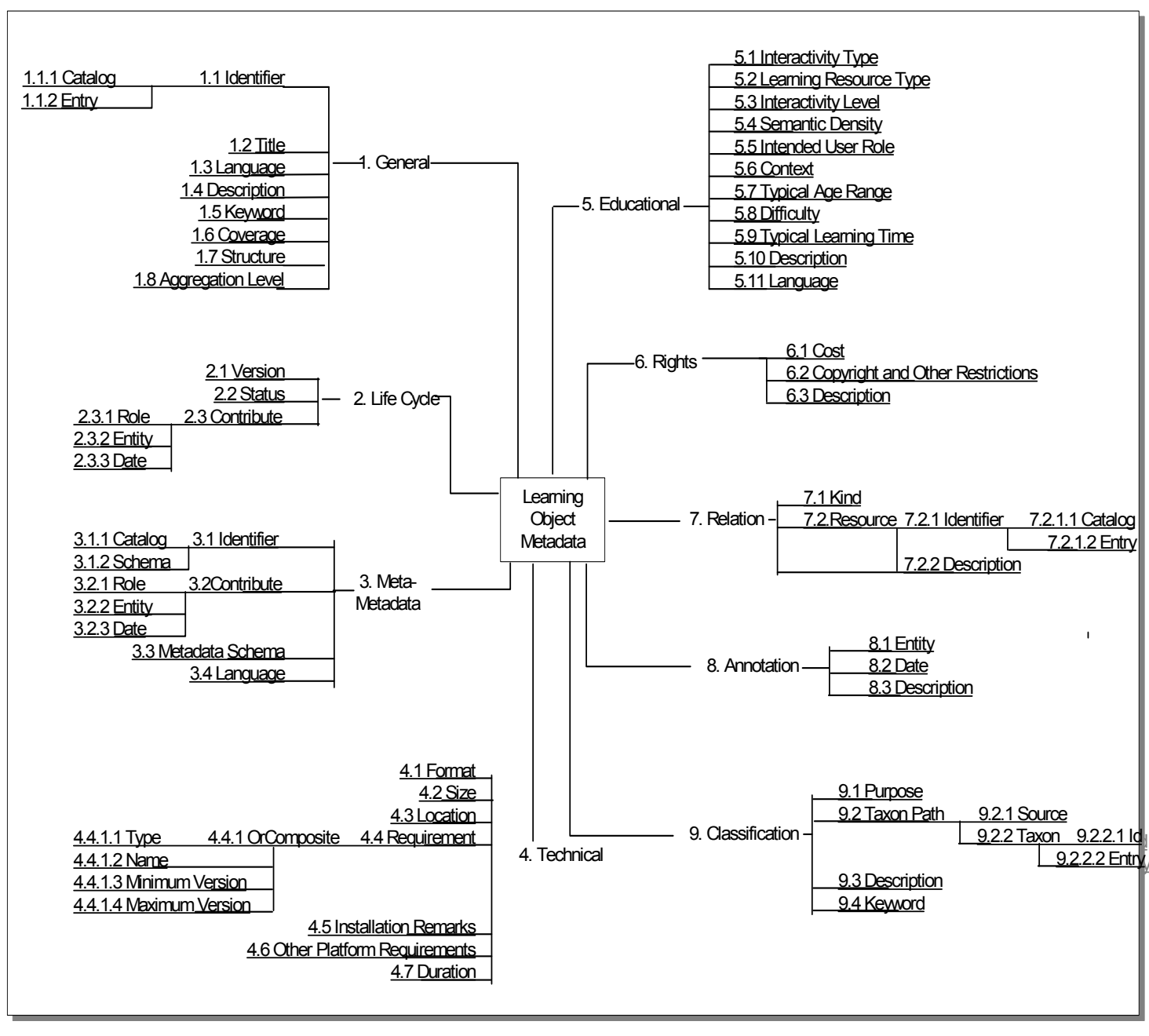

Schematic Presentation of the learning object metadata data model 


\section{Biographies}

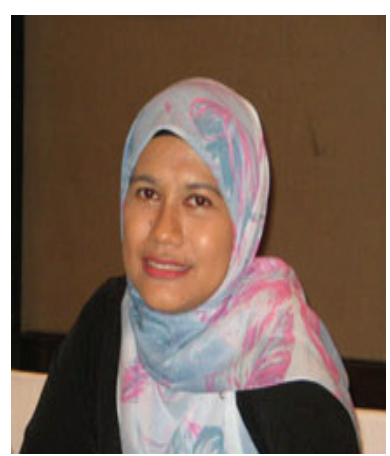

Yazrina Yahya is currently a senior lecturer at Department of Science and System Management, Faculty of Information Science and Technology, National University of Malaysia. She received a Ph.D. in Intelligent Multimedia from National University of Malaysia, M. Sc. in Business System Analysis and Design from City University, London and B. Sc. in Computer Science from National University of Malaysia. Her research interests include Web Based Technologies, System Analysis and Design, Semantic Web Technologies, Knowledge Management and Agent Based System.

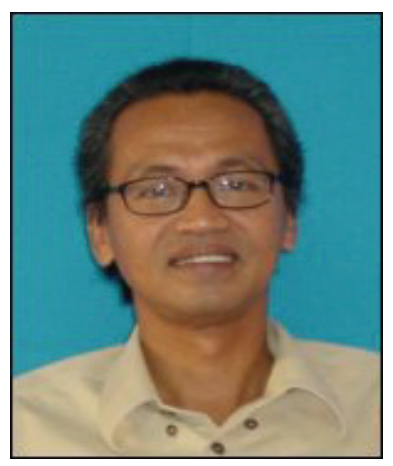

Mohammed Yusof is a Professor and the Dean of Faculty of Information Technology \& Multimedia Communication, Open University Malaysia. He is also the head of the research group Mobile Learning for FITMC.

He earned his Ph.D. and M. Sc. in Computer Science from Imperial College London. He is involved in the field of soft computing, systems thinking, IT Policy and Strategic Studies for many years. His current research interests are Intelligent Learning Management Systems, Mobile Learning, Web Based Technologies, Web Mining and Expert Systems. 